\title{
Marine algal flora of Flores and Corvo Islands, Azores
}

\author{
Ana I Azevedo Neto ${ }^{\ddagger}$, Manuela I. Parente§, Ian Tittleyl, Robert L. Fletcher", William Farnham \\ Ana C. Costa§, Andrea Z. Botelho§, Sandra Monteiro§, Roberto Resendes ${ }^{\#}$, Pedro Afonso ${ }^{\circledR}$, \\ Afonso C.L. Prestes ${ }^{\ddagger}$, Nuno V. Álvaro", David Mila-Figueras ${ }^{\star}$, Raul M. A. Neto", \\ José M. N. Azevedo $\ddagger$, Ignacio Moreu ${ }^{\ddagger}$ \\ ‡ cE3c - Centre for Ecology, Evolution and Environmental Changes/Azorean Biodiversity Group, Faculdade de Ciências e \\ Tecnologia, Departamento de Biologia, Universidade dos Açores, 9500-321 Ponta Delgada, Açores, Portugal \\ $\S \mathrm{CIBIO}$, Centro de Investigação em Biodiversidade e Recursos Genéticos, InBIO Laboratório Associado, Pólo dos Açores, \\ Universidade dos Açores, Faculdade de Ciências e Tecnologia, Departamento de Biologia, \\ 9500-321 Ponta Delgada, Açores, Portugal \\ | Natural History Museum, Cromwell Road, London, Code SW7 5BD, United Kingdom \\ II Institute of Marine Sciences, Department of Biological Sciences, University of Portsmouth, Ferry Road, Eastney, \\ Portsmouth, PO4 9LY, United Kingdom \\ \# Faculdade de Ciências e Tecnologia, Departamento de Biologia, Universidade dos Açores, \\ 9500-321 Ponta Delgada, Açores, Portugal \\ - IMAR/Okeanos, Departamento de Oceanografia e Pescas, Universidade dos Açores, Rua Prof. Doutor Frederico Machado, \\ 9901-862 Horta, Açores, Portugal \\ « CCMMG (Centro do Clima Meteorologia e Mudanças Globais) \& IITA-A (Instituto de Investigação e Tecnologias Agrárias e \\ do Ambiente), Universidade dos Açores, Faculdade de Ciências Agrárias, Rua Capitão João d'Ávila - Pico da Urze, 9700-042 \\ Angra do Heroísmo, Açores, Portugal \\ »NA, NA, Portugal
}

Corresponding author: Ana I Azevedo Neto (ana.im.neto@uac.pt)

Academic editor: Anne Thessen

Received: 19 Nov 2020 | Accepted: 23 Dec 2020 | Published: 03 Feb 2021

Citation: Neto AIA, Parente MI, Tittley I, Fletcher RL, Farnham W, Costa AC, Botelho AZ, Monteiro S, Resendes R, Afonso P, Prestes AC.L, Álvaro NV, Mila-Figueras D, Neto RMA, Azevedo JMN, Moreu I (2021) Marine algal flora of Flores and Corvo Islands, Azores. Biodiversity Data Journal 9: e60929.

https://doi.org/10.3897/BDJ.9.e60929

\section{Abstract}

\section{Background}

The algal flora of the western group of the Azores archipelago (Islands of Flores and Corvo) has attracted the interest of many researchers on numerous past occasions (such 
as Drouet 1866, Trelease 1897, Gain 1914, Schmidt 1929, Schmidt 1931, Azevedo et al. 1990, Fralick and Hehre 1990, Neto and Azevedo 1990, Neto and Baldwin 1990, Neto 1996, Neto 1997, Neto 1999, Tittley and Neto 1996, Tittley and Neto 2000, Tittley and Neto 2005, Tittley and Neto 2006, Azevedo 1998, Azevedo 1999, Tittley et al. 1998, Dionísio et al. 2008, Neto et al. 2008). Despite this interest, the macroalgal flora of the Islands cannot be described as well-known with the published information reflecting limited collections preformed in short-term visits by scientists. To overcome this, a thorough investigation, encompassing collections and presence data recording, has been undertaken for both the littoral and sublittoral regions, down to a depth of approximately $40 \mathrm{~m}$, covering a relatively large area on both Islands (approximately $143 \mathrm{~km}^{2}$ for Flores and $17 \mathrm{~km}^{2}$ for Corvo).

This paper lists the resultant taxonomic records and provides information on species ecology and occurrence around both these Islands, thereby improving the knowledge of the Azorean macroalgal flora at both local and regional scales.

\section{New information}

For the Island of Flores, a total of 1687 specimens (including some taxa identified only to genus level) belonging to 196 taxa of macroalgae are registered, comprising 120 Rhodophyta, 35 Chlorophyta and 41 Ochrophyta (Phaeophyceae). Of these taxa, 128 were identified to species level (80 Rhodophyta, 22 Chlorophyta and 26 Ochrophyta), encompassing 37 new records for the Island (20 Rhodophyta, 6 Chlorophyta and 11 Ochrophyta); two Macaronesian endemics (Laurencia viridis Gil-Rodríguez \& Haroun and Millerella tinerfensis (Seoane-Camba) S.M.Boo \& J.M.Rico); six introduced (the Rhodophyta Asparagopsis armata Harvey, Neoizziella divaricata (C.K.Tseng) S.-M.Lin, S.Y.Yang \& Huisman and Symphyocladia marchantioides (Harvey) Falkenberg; the Chlorophyta Codium fragile subsp. fragile (Suringar) Hariot; and the Ochrophyta Hydroclathrus tilesii (Endlicher) Santiañez \& M.J.Wynne and Papenfussiella kuromo (Yendo) Inagaki); and 14 species of uncertain status (10 Rhodophyta, two Chlorophyta and two Ochrophyta).

For the Island of Corvo, a total of 390 specimens distributed in 56 taxa of macroalgae are registered, comprising 30 Rhodophyta, nine Chlorophyta and 17 Ochrophyta (Phaeophyceae). Whilst a number of taxa were identified only to the genus level, 43 were identified to species level (22 Rhodophyta, eight Chlorophyta and 13 Ochrophyta), comprising 22 new records for the Island (nine Rhodophyta, four Chlorophyta and nine Ochrophyta), two introduced species (the Rhodophyta Asparagopsis armata and the Chlorophyta Codium fragile subsp. fragile and seven species of uncertain status (five Rhodophyta and two Ochrophyta).

\section{Keywords}

Macroalgae, Azores, Corvo Island, Flores Island, new records, endemism, native, uncertain, introduced, occurrence data. 


\section{Introduction}

The Azorean algal flora, considered cosmopolitan, with species shared with Macaronesia, North Africa, the Mediterranean Sea, Atlantic Europe and America (Tittley 2003, Tittley and Neto 2006, Wallenstein et al. 2009), is relatively rich when compared to that of other remote oceanic Islands (Neto et al. 2005, Tittley and Neto 2005, Wallenstein et al. 2009). Around 400 species of marine macroalgae have, to date, been recorded for the isolated mid-Atlantic Azores archipelago (Freitas et al. 2019). These authors, based on extensive analysis encompassing data on brachyurans, polychaetes, gastropods, echinoderms, coastal fishes and macroalgae, suggested that the Azores should be a biogeographical entity of its own and proposed a redefinition of the Lusitanian biogeographical province, in which they recognised four ecoregions: the South European Atlantic Shelf, the Saharan Upwelling, the Azores ecoregion and a new ecoregion herein named Webbnesia, which comprises the archipelagos of Madeira, Selvagens and the Canary Islands. In their paper comparing the Azorean algal flora to that of the new Webbnesia region, they reported that the Canary Islands, with 689 species of marine macroalgae, are by far the most diverse archipelago, followed by the Azores (405), Madeira (396) and Cabo Verde (333). The Selvagens are the least diverse one (295 species). It is worth mentioning that the published information reflects data from only a few of the nine Azorean Islands, since not all of them have been adequately investigated. In the Azores archipelago, São Miguel is by far the Island with the largest amount of research dedicated to the study of its algal flora. The total number of algal species is, at the moment, 260, a number that is likely to increase due to ongoing research by authors of the present paper. Most of the remaining Islands have received less attention. To overcome this and improve the understanding of the archipelago's macroalgal flora, research has been conducted over the past three decades on all the Islands. Data on the Islands of Pico, Graciosa and Terceira is already available on the recently-published papers (Neto et al. 2020a, Neto et al. 2020b, Neto et al. 2020c). Table 1 summarises the currently-available information.

Table 1.

Number of macroalgal species on the Azorean Islands (Neto et al. 2020b, Neto et al. 2020c, Neto et al. $2020 \mathrm{~d}$ and authors' unpublished data).

\begin{tabular}{|l|l|l|l|l|l|l|l|l|l|}
\hline Phyllum & Santa Maria & São Miguel & Terceira & Graciosa & São Jorge & Pico & Faial & Flores & Corvo \\
\hline Rhodophyta & 68 & 168 & 73 & 126 & 35 & 142 & 59 & 59 & 13 \\
\hline Chlorophyta & 20 & 39 & 24 & 31 & 17 & 41 & 16 & 16 & 2 \\
\hline Ochrophyta & 28 & 53 & 16 & 38 & 10 & 42 & 8 & 16 & 4 \\
\hline Total & 116 & 260 & 113 & 195 & 62 & 225 & 83 & 91 & 19 \\
\hline
\end{tabular}

To provide a better understanding of the archipelago's seaweed flora, a long term research programme of study has been undertaken, mainly by local investigators into the marine macroalgae flora on several of the less studied Azorean Islands. The present paper presents both physical and occurrence data and information gathered from surveys 
undertaken on Flores and Corvo Islands mainly by the Island Aquatic Research Group of the Azorean Biodiversity Centre of the University of the Azores (Link: https://ce3c.ciencias.ulisboa.pt/sub-team/island-aquatic-ecology), the BIOISLE, Biodiversity and Islands Research Group of CIBIO-Açores at the University of the Azores (Link: https://cibio.up.pt/research-groups-1/details/bioisle) and the OKEANOS Centre of the University of the Azores (Link: http://www.okeanos.uac.pt). In these surveys, particular attention was given to the small filamentous and thin sheet-like species that are often short-lived and fast-growing and usually very difficult to identify in the wild, without the aid of a microscope and specialised literature in the laboratory.

The present paper aims to provide a valuable marine biological tool for research on systematics, diversity and conservation, biological monitoring, climate change and ecology for academics, students, government, private organisations and the general public.

\section{General description}

Purpose: In this paper, we present taxonomic records of macroalgae recorded from the Islands of Flores and Corvo and provide general information on their occurrence and distribution. By doing this, we are contributing to address several biodiversity shortfalls (see Cardoso et al. 2011, Hortal et al. 2015), namely, the need to catalogue the Azorean macroalgae (Linnean shortfall) and improve the current information on their local and regional geographic distribution (Wallacean shortfall), as well as on species abundance and dynamics in space (Prestonian shortfall).

\section{Project description}

Title: Marine algal flora of Flores and Corvo Islands, Azores.

Personnel: Collections were made and occurrence data recorded over several years (1989 - 2018). Main collectors were Ana Cristina Costa, Ana I Neto, Andrea Z. Botelho, Carolina Arruda, Cláudia Hipólito, Cristiana Figueiredo, David Milla-Figueras, Heather Baldwin, Inês Neto, Joana Michael, José M. N. Azevedo, lan Tittley, Manuela I. Parente, Marco Henrique, Maria Ana Dionísio, Maria Ventura, Nuno Vaz Álvaro, Patrícia Madeira, Pedro Cerqueira, Raul Neto, Rita Grilo, Rita Norberto, Robert Fletcher, Sandra Monteiro and William Farnham.

Preliminary in situ identifications were carried out by: Ana Cristina Costa, Ana I Neto, Andrea Z. Botelho, David Milla-Figueras, Heather Baldwin, Ian Tittley, Manuela I. Parente, Maria Ventura, Rita Grilo, Robert Fletcher and William Farnham.

Ana I. Neto, Andrea Z. Botelho, David Milla-Figueras, lan Tittley, Manuela I. Parente, Robert Fletcher and William Farnham were responsible for the final species identification. 
Voucher specimen management was mainly undertaken by Afonso Prestes, Ana I. Neto, Andrea Z. Botelho, David Milla-Figueras, Eunice Nogueira, Manuela I. Parente, Natália Cabral and Roberto Resendes.

Study area description: The Azores archipelago $\left(38^{\circ} 43^{\prime} 49^{\prime \prime} \mathrm{N}, 27^{\circ} 19^{\prime} 10^{\prime \prime} \mathrm{W}\right.$, Fig. 1), comprising nine Islands and several islets, is spread over $500 \mathrm{~km}$, in a WNW direction. The Islands emerged from what is called the Azores Plateau and are located above an active triple junction between three of the world's largest tectonic plates (the North American Plate, the Eurasian Plate and the African Plate, Hildenbrand et al. 2018). Flores and Corvo (in black in Fig. 1), the westernmost Islands of the archipelago, are located in the North American Plate, whereas the remaining Islands are located around the boundary that divides the Eurasian and African Plates (Hildenbrand et al. 2018).

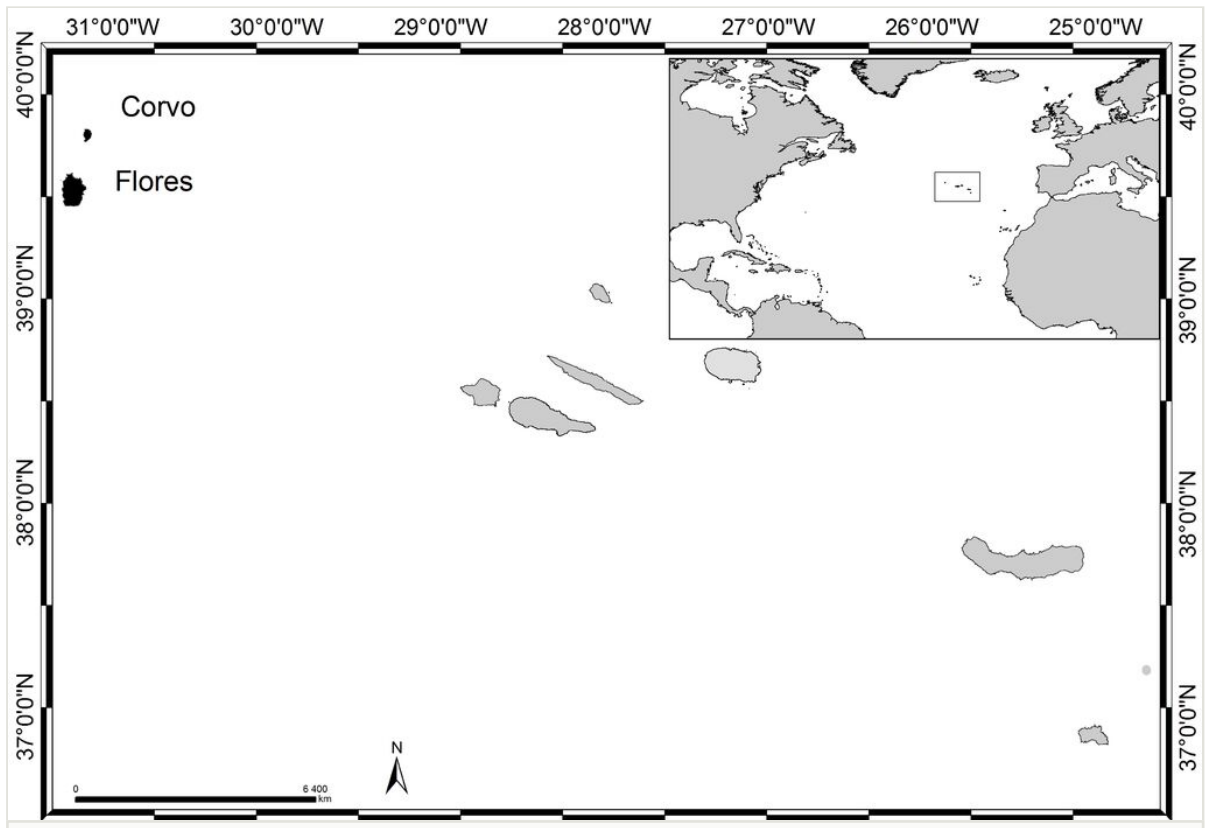

Figure 1. doi

The Azores, its location in the Atlantic and Flores and Corvo Islands highlighted in black (by Nuno V. Álvaro).

The Islands of Flores and Corvo are sub-aerial domains of a large volcanic formation, mostly submarine, implanted on an oceanic crust and aged between 9.0 and 10.0 million years (Ma). Each of these Islands has unique geomorphological characteristics: Flores $\left(39^{\circ} 31^{\prime} 27^{\prime \prime} \mathrm{N},-31^{\circ} 15^{\prime} 31 \mathrm{~W} \mathrm{~W}\right.$, Fig. 2), of approximately $141 \mathrm{~km}^{2}$, is composed of two units, the central massif located in the central plain and the coastal periphery; Corvo, its neighbour $\left(39^{\circ} 43^{\prime} 37^{\prime \prime} \mathrm{N},-31^{\circ} 7^{\prime} 44^{\prime \prime} \mathrm{W}\right.$, Fig. 3), of approximately $17 \mathrm{~km}^{2}$, is a crater of a major Plinian eruption and the smallest Island of the Azores archipelago (Azevedo 1999). The climate, as in the remaining Islands, is characterised by regular and abundant rainfall, high levels of 
relative humidity and persistent winds, mainly during the winter and autumn seasons (Morton et al. 1998). Fog is common and almost permanent at the higher elevations.

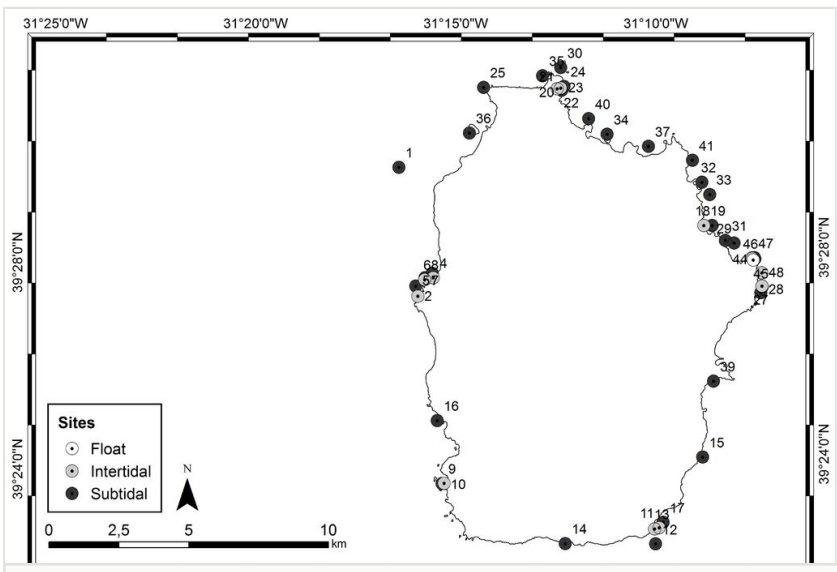

Figure 2. doi

Flores Island showing the sampling locations (by Nuno V. Álvaro).

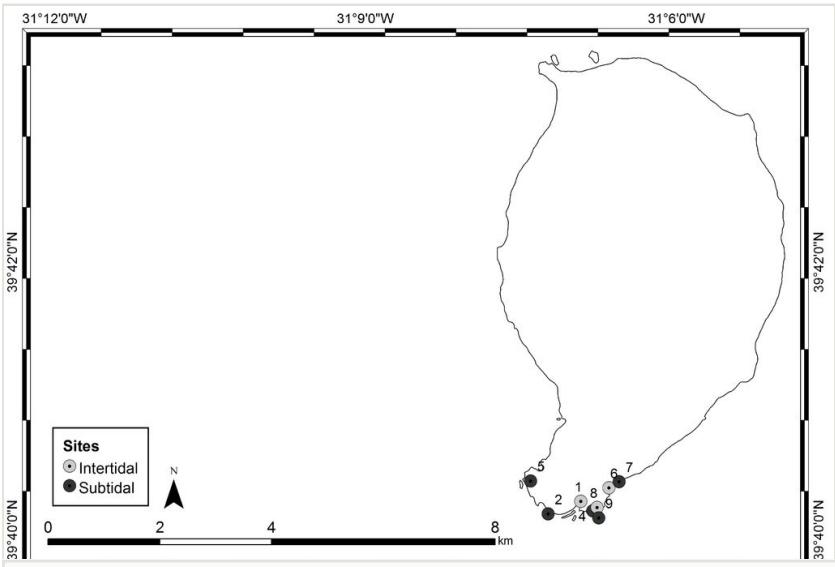

Figure 3. doi

Corvo Island showing the sampling locations (by Nuno V. Álvaro).

Marine action is responsible for the predominance of erosive morphologies in the coastal areas of both Islands, examples of which on Flores (Neto et al. 2008) are: the valleys associated with fluvial erosion (Vales das Lajes and da Fazenda); the coastal or back cliffs (Fajãzinha - Ponta da Fajã); the large marine abrasion platforms (Fajãzinha - Fajã Grande); and the coastal platforms associated with landslides and collapses (Ponta da Fajã).

Owing to the lack of a continental shelf that characterises most volcanic Islands, coastal extension is restricted and deep waters occur within a few kilometres offshore. The tidal 
range is small ( $<2 \mathrm{~m}$, Hidrogrográfico 1981) and coasts are subjected to swell and surge for most of the year.

The Islands' coastline, approximately 72.209 km long on Flores and $19.045 \mathrm{~km}$ long on Corvo, is predominantly rocky, subject to strong maritime erosion and presents an irregular slope with extensive and high cliffs cut by waterfalls and streams, alternating with a complex system of bays, rocky beaches and natural terraces (Azevedo 1999). The bottom is mostly made up of irregular rocky bedrock, containing, in some places, pockets of sediment of coarse sand and gravel, alternating with places covered by blocks that rest on either the rocky bed or the sediment. Submerged or semi-submerged caves, arches and tunnels of small amplitude and reduced length are common. As depth increases, the slope decreases, although the bottom is still rocky and uneven. This feature is interrupted by valleys and other structures of smooth to rough relief. The sediment floor in the deepest areas is stable, generally composed of medium and/or coarse sand. From this floor arise small islets with normally vertical walls and low irregular crowns, marked by ridges and valleys (Neto et al. 2008). Along the coastline and islets, natural sheltered habitats (arches and semi-submerged caves, tide pools) create favourable conditions for the growth of juveniles and adults of coastal fish. The constant recycling of nutrients caused by the wave-exposed coasts of these Islands, provides suitable conditions for the occurrence of considerable diversity and abundance of macroinvertebrates and pelagic and benthic fish (Neto et al. 2008). At the foot of the cliffs, the rocky intertidal zone is, as elsewhere in the Azores, dominated by algal communities that form mosaic and/or horizontal bands relative to tide level and are made up of multispecific algal turfs (growth forms of either diminutive algae or diminutive forms of larger species) that carpet the rocks. In the intertidal, a distinct zonation pattern is evident. The higher zone, dominated by invertebrates (littorinids and chthamalid barnacles, Fig. 4), gives rise below to a mid-shore zone covered by algal turfs that create a dense, compact mat $20-30 \mathrm{~mm}$ in thickness, Fig. 5). The turf can be monospecific (of either Caulacanthus ustulatus (Turner) Kützing, Centroceras clavulatum (C. Agardh) Montagne or Gymnogongrus) or multispecific and composed by soft algae (e.g. Centroceras clavulatum, Ceramium and Chondracanthus) usually growing as epiphytes over articulate calcareous forms (e.g. Ellisolandia and Jania). The low-shore zone is mainly dominated by calcareous crusts (first/basal strata), covered by corticated macrophytes, for example, Ellisolandia elongata (J.Ellis \& Solander) K.R.Hind \& G.W.Saunders (Fig. 6) and Pterocladiella capillacea (S.G.Gmelin) Santelices \& Hommersand (Fig. 7) and, in more exposed locations, Tenarea tortuosa (Esper) Me Lemoine (Neto et al. 2008). Seasonally and mainly in spring and summer, the introduced red alga Asparagopsis armata occurs often abundantly at this lower intertidal level. Important features and habitats at this shore level are rock pools, occurring in different shapes and sizes and often recreating a shallow subtidal habitat, which contains a rich diversity of marine life. A few shores consist of irregularly rounded boulders or cobbles between which coarse sand or gravel may be retained. Sandy shores are rare (Neto, pers. observ.). The rocky bottoms in the submerged zone are covered by more frondose macrophytes, such as Pterocladiella capillacea, Halopteris filicina (Grateloup) Kützing, Dictyota spp. or Zonaria tournefortii (J.V.Lamouroux) Montagne (Fig. 8). At this level, the edible barnacles Megabalanus azoricus (Pilsbry, 1916) and/or the limpets Patella aspera 
Röding, 1798 are concentrated in the first few metres, while the slipper lobsters Scyllarides latus (Latreille, 1803) or the spiny lobsters Palinurus elephas (Fabricius, 1787) are found at greater depths. Several species of fish, such as the blue wrasse Symphodus caeruleus (Azevedo, 1999) or the ornate wrasse Thalassoma pavo (Linnaeus, 1758), are particularly frequent in shallow rocky areas, whereas other fish take shelter in crevices during the day, such as the morays, Muraena helena Linnaeus, 1758 or the forkbeards Phycis phycis (Linnaeus, 1766). Still other species roam amongst rocky reefs, such as the parrotfish Sparisoma cretense (Linnaeus, 1758), the salemas Sarpa salpa (Linnaeus, 1758) and the white sea bream Diplodus sargus (Linnaeus, 1758). In the numerous sea caves around Flores and Corvo, the dusky grouper Epinephelus marginatus (Lowe, 1834) occurs with an unknown frequency in most of the other Islands (Neto et al. 2008).

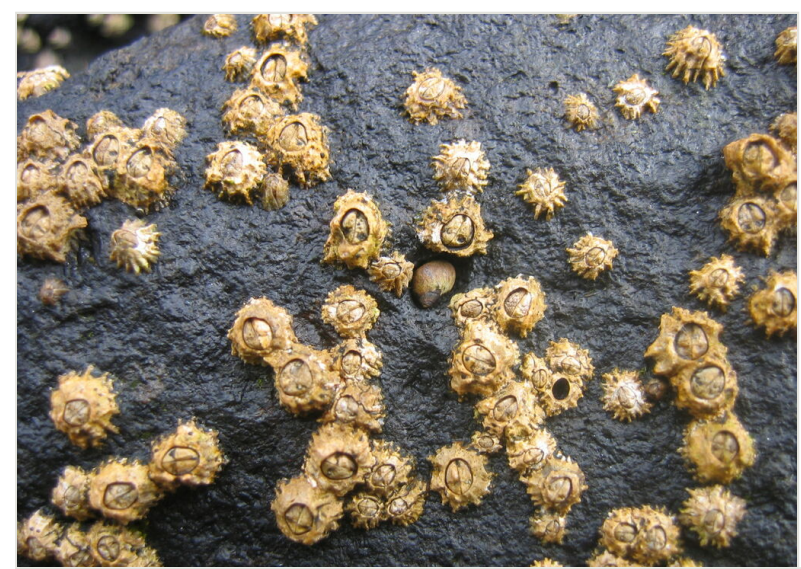

Figure 4. doi

Chthamalid barnacles and littorinids, characteristic species of the Azorean high intertidal level (by the Island Aquatic Ecology Subgroup of cE3c-ABG).

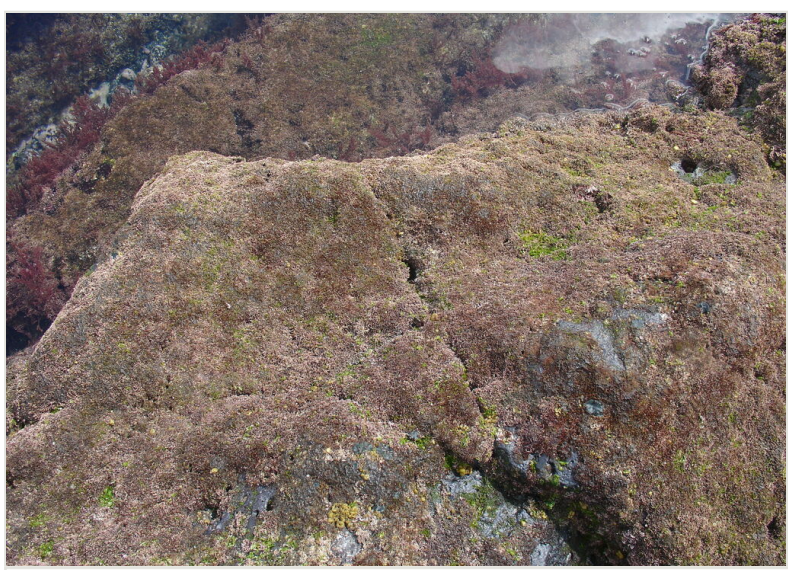

Figure 5. doi

Algal turfs at the low-shore intertidal level (by the Island Aquatic Ecology Subgroup of cE3c$A B G)$. 


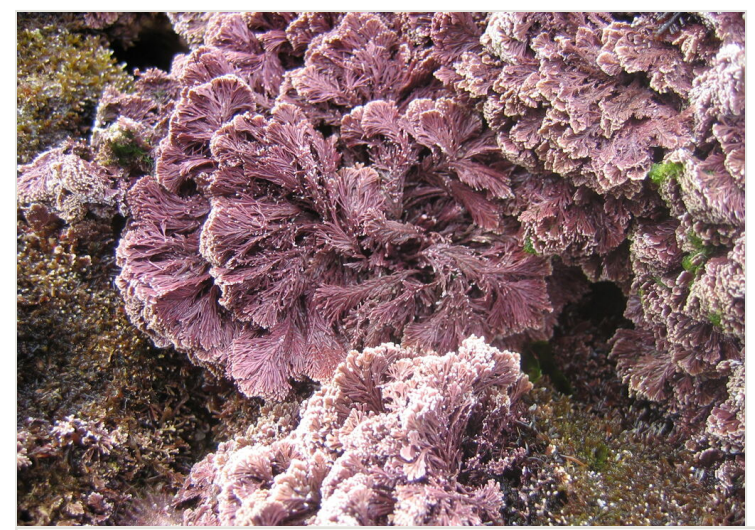

Figure 6. doi

The calcareous frondose alga Ellisolandia elongata at the low intertidal level (by the Island Aquatic Ecology Subgroup of cE3c-ABG).

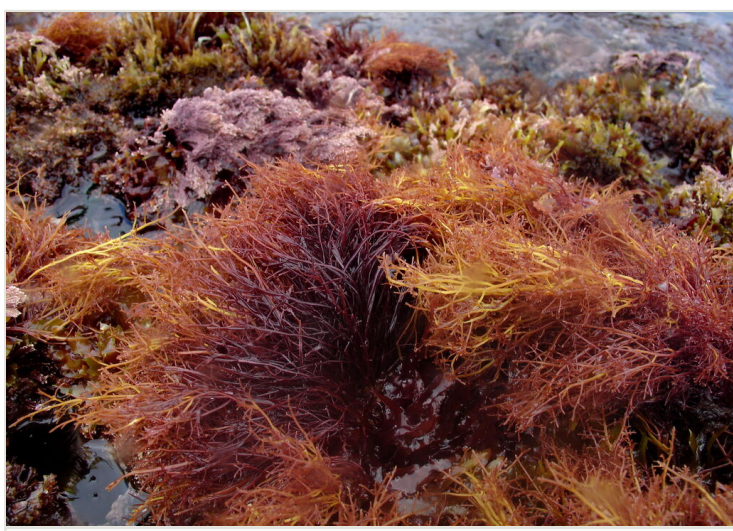

Figure 7. doi

The red agarophyte Pterocladiella capillacea, a common species at the low intertidal level (by the Island Aquatic Ecology Subgroup of cE3c-ABG).

In 2007, both Flores and Corvo Islands were recognised by UNESCO as a Biosphere Reserve and thus integrated into the programme "The Man and the Biosphere". The programme focuses on the ecological, social and economic dimensions of biodiversity loss and uses the World Network of Biosphere Reserves as a vehicle for knowledge sharing, research and monitoring, education and training and participatory decision-making with local communities. The proposed area for the Biosphere Reserve includes the entire emerged land area of the Islands and a surrounding marine zone, covering a total area of 58,619 hectares in Flores and 25,853 hectares in Corvo and incorporating an important diversity of habitats of regional, national and international importance, which includes, for example, areas integrated in the Natura 2000 Network. The inclusion of a vast marine area promotes explicitly, along with conservation, an integrated management practice between terrestrial, coastal and marine environments (Neto et al. 2008). 


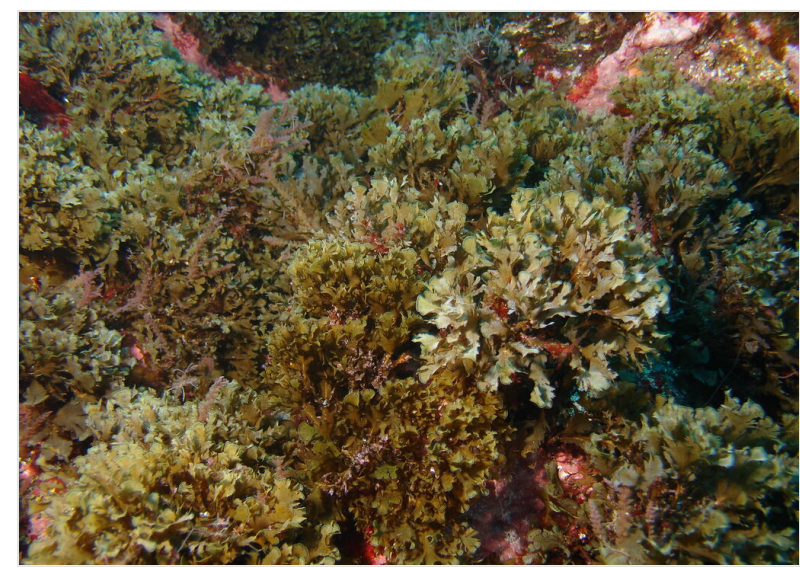

Figure 8. doi

The frondose brown macrophyte Zonaria tournefortii at the subtidal level (by the Island Aquatic Ecology Subgroup of cE3c-ABG).

Design description: The algae referred to in this paper were collected during field surveys from both the littoral and sublittoral regions down to approximately $40 \mathrm{~m}$ on the Islands of Flores and Corvo. Each sampling location was visited several times. On each occasion, a careful and extensive survey was undertaken to provide good coverage of the area. Both presence recording and physical collections were made by walking over the shores or by SCUBA diving. The specimens collected were taken to the laboratory for identification and preservation and the resulting vouchers were deposited in the AZB Herbarium Ruy Telles Palhinha and the Molecular Systematics Laboratory at the Faculty of Sciences and Technology of the University of the Azores.

Funding: This study was mainly financed by the following projects/scientific expeditions:

- Projects:

IASTFC- "Impact Assessment Study for the construction of the Transport Infrastructures of the Islands of Flores and Corvo, Azores - natural environment", funded by the Azores Regional Government - Regional Secretariat for Tourism and Environment / Regional Environment Directorate, 1990;

- LFFC- "Littoral flora of the islands of Flores and Corvo: Inventory, ecology and biogeographic affinities", Government of the Azores - Regional Secretariat for Tourism and Environment / Regional Environment Directorate (GRA-SRTA / DRA), 1995-1999;

- Project Flores- Biosphere - "Application of Flores Island to a Biosphere Reserve". Government of the Azores - Regional Secretariat for the Environment and the Sea (GRA-SRAM). 2007-2008;

- $\quad$ Project MOST - "Application of a model of sustainable tourism to areas of Natura 2000 network in the Azores" (PTDC / AAC-AMB / 104714/2008). Foundation for Science and Technology and the Government of the 
Azores - Regional Secretariat for the Sea, Science and Technology, Regional Directorate for Sea Affairs (GRA / SRMCT-DRAM), 2010 - 2013;

- $\quad$ Project PIMA - "Elaboration of the implementation program of the Marine Strategy Framework Directive - Marine Invasion Program in the Azores" (3/ DRAM /2015). Government of the Azores - Regional Secretariat for the Sea, Science and Technology, Regional Directorate for Sea Affairs (GRA / SRMCT-DRAM), 2015;

- Project BALA - "Elaboration of the implementation program of the marine strategy framework directive - biodiversity of the coastal environments of the Azores" (2 /DRAM /2015). Government of the Azores - Regional Secretariat for the Sea, Science and Technology, Regional Directorate for Sea Affairs (GRA / SRMCT-DRAM), 2015;

Project "ACORES-01-0145-FEDER-000072 - AZORES BIOPORTAL PORBIOTA. Operational Programme Azores 2020 (85\% ERDF and 15\% regional funds);

- Scientific Expeditions and campaigns:

"FLORES/89", organised by the Biology Department of the University of the Azores, Flores Island, Azores, July 1989;

- "Earthwatch FLORES/95", a joint organisation of the Marine Biology Section of the Biology Department of the University of the Azores and the Natural History Museum (London), co-funded by the Earthwatch International and developed under the project LFFC, July - August 1995;

"FLORES \& CORVO/99", developed under the project LFFC, July 1999;

"FLORES \& CORVO/2007", XIII Scientific Expedition of the Biology Department of the University of the Azores, Islands of Flores and Corvo, July 2007;

"MOST", under the project MOST, 2011-2013;

"PIMA/BALA", under the projects PIMA and BALA, 2015;

- Other funds:

Portuguese National Funds, through FCT- Fundação para a Ciência e a Tecnologia, within the projects UID/BIA/00329/2013, 2015-2019, UID/BIA/ 00329/2020-2023 and UID/BIA/50027/2019 and POCl-01-0145FEDER-006821;

- ERDF funds through the Operational Programme for Competitiveness Factors - COMPETE;

- Portuguese Regional Funds, through DRCT - Regional Directorate for Science and Technology, within several projects, 2019 and 2020 and SRMCT / DRAM - Regional Secretariat for the Sea, Science and Technology, Regional Directorate for Sea Affairs;

- $\quad$ CIRN/DB/UAc (Research Centre for Natural Resources, Universidade dos Açores, Departamento de Biologia);

CIIMAR (Interdisciplinary Centre of Marine and Environmental Research, Porto, Portugal). 


\section{Sampling methods}

Study extent: This study covers a relatively large area, of approximately $143 \mathrm{~km}^{2}$ on Flores and $17 \mathrm{~km}^{2}$ on Corvo, covering littoral and sublittoral levels down to approximately $40 \mathrm{~m}$ around the Islands (Tables 2, 3, Figs 2, 3).

\section{Table 2.}

Information and location of the sampling sites on Flores Island.

\begin{tabular}{|c|c|c|c|c|c|}
\hline $\begin{array}{l}\text { Location } \\
\text { No }\end{array}$ & Location ID & Municipality & Locality & $\begin{array}{l}\text { Latitude / } \\
\text { Longitude }\end{array}$ & $\begin{array}{l}\text { Littoral } \\
\text { zone }\end{array}$ \\
\hline 1 & FLO_bris & & Baixa Rasa do Ilhéu & $\begin{array}{l}39,495215 \\
-31,274644\end{array}$ & Subtidal \\
\hline 2 & FLO_L_FGem & Lajes & Fajã Grande | Entre-marés & $\begin{array}{l}39,453485 \\
-31,267758\end{array}$ & Intertidal \\
\hline 3 & FLO_L_FGprb & Lajes & $\begin{array}{l}\text { Fajã Grande | Porto de Recreio | } \\
\text { Baía }\end{array}$ & $\begin{array}{l}39,460831 \\
-31,261651\end{array}$ & Subtidal \\
\hline 4 & FLO_L_FGprem & Lajes & $\begin{array}{l}\text { Fajã Grande | Porto de Recreio | } \\
\text { Entre-marés }\end{array}$ & $\begin{array}{l}39,459356 \\
-31,261244\end{array}$ & Intertidal \\
\hline 5 & FLO_L_FGpvb & Lajes & Faja Grande | Porto Velho | Baía & $\begin{array}{l}39,456795 \\
-31,268607\end{array}$ & Subtidal \\
\hline 6 & FLO_L_FGpvb & Lajes & Faja Grande | Porto Velho | Baía & $\begin{array}{l}39,458818 \\
-31,264851\end{array}$ & Intertidal \\
\hline 7 & FLO_L_FGpve & Lajes & $\begin{array}{l}\text { Fajã Grande | Porto Velho | } \\
\text { Enseada }\end{array}$ & $\begin{array}{l}39,459471 \\
-31,264743\end{array}$ & Subtidal \\
\hline 8 & FLO_L_FGpvem & Lajes & $\begin{array}{l}\text { Faja Grande | Porto Velho | Entre- } \\
\text { marés }\end{array}$ & $\begin{array}{l}39,458818 \\
-31,264851\end{array}$ & Intertidal \\
\hline 9 & FLO_L_Ls & Lajes & Lajedo & $\begin{array}{l}39,392978 \\
-31,259311\end{array}$ & Subtidal \\
\hline 10 & FLO_L_Lnt & Lajes & Lajedo | Nascente termal & $\begin{array}{l}39,393021 \\
-31,258356\end{array}$ & Intertidal \\
\hline 11 & FLO_L_Lapem & Lajes & $\begin{array}{l}\text { Lajes | Atrás do Porto | Entre- } \\
\text { marés }\end{array}$ & $\begin{array}{l}39,377324 \\
-31,169366\end{array}$ & Intertidal \\
\hline 12 & FLO_L_Laps & Lajes & Lajes | Atrás do Porto | Subtidal & $\begin{array}{l}39,372111 \\
-31,17103\end{array}$ & Subtidal \\
\hline 13 & FLO_L_Lem & Lajes & Lajes | Entre-marés & $\begin{array}{l}39,376978 \\
-31,171336\end{array}$ & Intertidal \\
\hline
\end{tabular}




\begin{tabular}{|c|c|c|c|c|c|}
\hline $\begin{array}{l}\text { Location } \\
\text { No }\end{array}$ & Location ID & Municipality & Locality & $\begin{array}{l}\text { Latitude / } \\
\text { Longitude }\end{array}$ & $\begin{array}{l}\text { Littoral } \\
\text { zone }\end{array}$ \\
\hline 14 & FLO_L_Flvs & Lajes & Lajes | Fajã de Lopo Vaz & $\begin{array}{l}39,372801 \\
-31,208518\end{array}$ & Subtidal \\
\hline 15 & FLO_L_Fpls & Lajes & Lajes | Fazenda | Porto da Lomba & $\begin{array}{l}39,399797 \\
-31,150731\end{array}$ & Subtidal \\
\hline 16 & FLO_L_Ms & Lajes & Lajes | Mosteiro & $\begin{array}{l}39,413261 \\
-31,260714\end{array}$ & Subtidal \\
\hline 17 & FLO_L_Lp & Lajes & Lajes | Porto & $\begin{array}{l}39,379015 \\
-31,167686\end{array}$ & Subtidal \\
\hline 18 & FLO_SC_CAb & Santa Cruz & Cedros | Alagoa | Baía & $\begin{array}{l}39,474441 \\
-31,144853\end{array}$ & Subtidal \\
\hline 19 & FLO_SC_CAem & Santa Cruz & Cedros | Alagoa | Entre-marés & $\begin{array}{l}39,474473 \\
-31,148271\end{array}$ & Intertidal \\
\hline 20 & FLO_SC_PDapem & Santa Cruz & $\begin{array}{l}\text { Ponta Delgada | Atrás do Porto | } \\
\text { Entre-marés }\end{array}$ & $\begin{array}{l}39,519728 \\
-31,206613\end{array}$ & Intertidal \\
\hline 21 & FLO_SC_PDaps & Santa Cruz & $\begin{array}{l}\text { Ponta Delgada | Atrás do Porto | } \\
\text { Subtidal }\end{array}$ & $\begin{array}{l}39,519568 \\
-31,206579\end{array}$ & Subtidal \\
\hline 22 & FLO_SC_PDpem & Santa Cruz & $\begin{array}{l}\text { Ponta Delgada | Porto | Entre- } \\
\text { marés }\end{array}$ & $\begin{array}{l}39,519473 \\
-31,208125\end{array}$ & Intertidal \\
\hline 23 & FLO_SC_PDpes & Santa Cruz & Ponta Delgada | Porto | Este & $\begin{array}{l}39,519017 \\
-31,206235\end{array}$ & Subtidal \\
\hline 24 & FLO_SC_PDpos & Santa Cruz & Ponta Delgada | Porto | Oeste & $\begin{array}{l}39,520223 \\
-31,205269\end{array}$ & Subtidal \\
\hline 25 & FLO_SC_PDFAs & Santa Cruz & Farol de Albernaz & $\begin{array}{l}39,520461 \\
-31,238744\end{array}$ & Subtidal \\
\hline 26 & FLO_SC_SCaps & Santa Cruz & Santa Cruz | Atrás do porto & $\begin{array}{l}39,452411 \\
-31,125155\end{array}$ & Subtidal \\
\hline 27 & FLO_SC_SCapvem & Santa Cruz & Santa Cruz | Atrás do porto velho & $\begin{array}{l}39,454593 \\
-31,124608\end{array}$ & Intertidal \\
\hline 28 & FLO_SC_SCapvem & Santa Cruz & $\begin{array}{l}\text { Santa Cruz | Atrás do porto velho } \\
\text { | Entre-marés }\end{array}$ & $\begin{array}{l}39,454593 \\
-31,124608\end{array}$ & Intertidal \\
\hline 29 & FLO_SC_SCbvs & Santa Cruz & Santa Cruz | Baixa vermelha & $\begin{array}{l}39,46859 \\
-31,135821\end{array}$ & Subtidal \\
\hline 30 & FLO_SC_SCbpds & Santa Cruz & $\begin{array}{l}\text { Santa Cruz | Baixas de Ponta } \\
\text { Delgada }\end{array}$ & $\begin{array}{l}39,526318 \\
-31,206453\end{array}$ & Subtidal \\
\hline
\end{tabular}




\begin{tabular}{|c|c|c|c|c|c|}
\hline $\begin{array}{l}\text { Location } \\
\text { No }\end{array}$ & Location ID & Municipality & Locality & $\begin{array}{l}\text { Latitude / } \\
\text { Longitude }\end{array}$ & $\begin{array}{l}\text { Littoral } \\
\text { zone }\end{array}$ \\
\hline 31 & FLO_SC_SCfs & Santa Cruz & Santa Cruz | Fazenda & $\begin{array}{l}39,469496 \\
-31,139423\end{array}$ & Subtidal \\
\hline 32 & FLO_SC_SCiars & Santa Cruz & $\begin{array}{l}\text { Santa Cruz | Ilhéu de Álvaro } \\
\text { Rodrigues }\end{array}$ & $\begin{array}{l}39,488436 \\
-31,148651\end{array}$ & Subtidal \\
\hline 33 & FLO_SC_SCigs & Santa Cruz & Santa Cruz | Ilhéu do Garajau & $\begin{array}{l}39,48444 \\
-31,145556\end{array}$ & Subtidal \\
\hline 34 & FLO_SC_SCias & Santa Cruz & Santa Cruz | Ilhéu dos Abrões & $\begin{array}{l}39,504518 \\
-31,187712\end{array}$ & Subtidal \\
\hline 35 & FLO_SC_SCifs & Santa Cruz & Santa Cruz | Ilhéu Francisco & $\begin{array}{l}39,523814 \\
-31,214148\end{array}$ & Subtidal \\
\hline 36 & FLO_SC_SCimvs & Santa Cruz & Santa Cruz | Ilhéu Maria Vaz & $\begin{array}{l}39,505833 \\
-31,245\end{array}$ & Subtidal \\
\hline 37 & FLO_SC_SCipas & Santa Cruz & Santa Cruz | Ilhéu Pão de Açucar & $\begin{array}{l}39,500367 \\
-31,170582\end{array}$ & Subtidal \\
\hline 38 & FLO_SC_SCpiem & Santa Cruz & $\begin{array}{l}\text { Santa Cruz | Piscinas | Entre- } \\
\text { marés }\end{array}$ & $\begin{array}{l}39,458842 \\
-31,124608\end{array}$ & Intertidal \\
\hline 39 & FLO_SC_SCpcs & Santa Cruz & Santa Cruz | Ponta da Caveira & $\begin{array}{l}39,424187 \\
-31,145587\end{array}$ & Subtidal \\
\hline 40 & FLO_SC_SCpis & Santa Cruz & Santa Cruz | Ponta do Ihéu & $\begin{array}{l}39,509661 \\
-31,19527\end{array}$ & Subtidal \\
\hline 41 & FLO_SC_SCpros & Santa Cruz & Santa Cruz | Ponta Ruiva | Oeste & $\begin{array}{l}39,495572 \\
-31,152406\end{array}$ & Subtidal \\
\hline 42 & FLO_SC_SCpbbd & Santa Cruz & $\begin{array}{l}\text { Santa Cruz | Porto da Baleia | } \\
\text { Baía | Deep }\end{array}$ & $\begin{array}{l}39,463387 \\
-31,127258\end{array}$ & Subtidal \\
\hline 43 & FLO_SC_SCpbbs1 & Santa Cruz & $\begin{array}{l}\text { Santa Cruz | Porto da Baleia | } \\
\text { Baía | Shallow } 1\end{array}$ & $\begin{array}{l}39,463035 \\
-31,128021\end{array}$ & Subtidal \\
\hline 44 & FLO_SC_SCpbbs2 & Santa Cruz & $\begin{array}{l}\text { Santa Cruz | Porto da Baleia | } \\
\text { Baía | Shallow } 2\end{array}$ & $\begin{array}{l}39,463731 \\
-31,12752\end{array}$ & Subtidal \\
\hline 45 & FLO_SC_SCpbbb & Santa Cruz & $\begin{array}{l}\text { Santa Cruz | Porto da Baleia | } \\
\text { Bóia flutuante }\end{array}$ & $\begin{array}{l}39,463035 \\
-31,128021\end{array}$ & Bóia \\
\hline 46 & FLO_SC_SCpbem1 & Santa Cruz & $\begin{array}{l}\text { Santa Cruz | Porto da Baleia | } \\
\text { Entre-marés } 1\end{array}$ & $\begin{array}{l}39,463518 \\
-31,128256\end{array}$ & Intertidal \\
\hline 47 & FLO_SC_SCpbem2 & Santa Cruz & $\begin{array}{l}\text { Santa Cruz | Porto da Baleia | } \\
\text { Entre-marés } 2\end{array}$ & $\begin{array}{l}39,463686 \\
-31,128523\end{array}$ & Intertidal \\
\hline
\end{tabular}




\begin{tabular}{|l|l|l|l|l|l|}
\hline $\begin{array}{l}\text { Location } \\
\text { No }\end{array}$ & Location ID & Municipality & Locality & $\begin{array}{l}\text { Latitude / } \\
\text { Longitude }\end{array}$ & $\begin{array}{l}\text { Littoral } \\
\text { zone }\end{array}$ \\
\hline 48 & FLO_SC_SCpvs & Santa Cruz & $\begin{array}{l}\text { Santa Cruz | Porto velho I } \\
\text { Shallow }\end{array}$ & $\begin{array}{l}39,454305 ; \\
-31,12449\end{array}$ & Subtidal \\
\hline
\end{tabular}

\section{Table 3.}

Information and location of the sampling sites on Corvo Island.

\begin{tabular}{|c|c|c|c|c|c|}
\hline $\begin{array}{l}\text { Location } \\
\text { No }\end{array}$ & Location ID & Municipality & Locality / Latitude & Longitude & $\begin{array}{l}\text { Littoral } \\
\text { zone }\end{array}$ \\
\hline 1 & COR_VC_VCaaem & $\begin{array}{l}\text { Vila do } \\
\text { Corvo }\end{array}$ & Vila do Corvo |Atrás do aeroporto & $\begin{array}{l}39,670289 \\
-31,115366\end{array}$ & Intertidal \\
\hline 2 & COR_VC_VCms & $\begin{array}{l}\text { Vila do } \\
\text { Corvo }\end{array}$ & Vila do Corvo | Moldinho & $\begin{array}{l}39,668742 \\
-31,120615\end{array}$ & Subtidal \\
\hline 3 & COR_VC_VCps & $\begin{array}{l}\text { Vila do } \\
\text { Corvo }\end{array}$ & Vila do Corvo | Pesqueiro & $\begin{array}{l}39,669127 \\
-31,113446\end{array}$ & Subtidal \\
\hline 4 & COR_VC_VCps & $\begin{array}{l}\text { Vila do } \\
\text { Corvo }\end{array}$ & Vila do Corvo | Pesqueiro & $\begin{array}{l}39,669127 \\
-31,113446\end{array}$ & Subtidal \\
\hline 5 & COR_VC_VCpas & $\begin{array}{l}\text { Vila do } \\
\text { Corvo }\end{array}$ & Vila do Corvo | Portinho da Areia & $\begin{array}{l}39,672838 \\
-31,123437\end{array}$ & Subtidal \\
\hline 6 & COR_VC_VCpem & $\begin{array}{l}\text { Vila do } \\
\text { Corvo }\end{array}$ & $\begin{array}{l}\text { Vila do Corvo | Porto da Casa | } \\
\text { Entre-marés }\end{array}$ & $\begin{array}{l}39,671968 \\
-31,110846\end{array}$ & Intertidal \\
\hline 7 & COR_VC_VCps & $\begin{array}{l}\text { Vila do } \\
\text { Corvo }\end{array}$ & $\begin{array}{l}\text { Vila do Corvo | Porto da Casa | } \\
\text { Subtidal }\end{array}$ & $\begin{array}{l}39,672729 \\
-31,109214\end{array}$ & Subtidal \\
\hline 8 & COR_VC_VCpbem & $\begin{array}{l}\text { Vila do } \\
\text { Corvo }\end{array}$ & $\begin{array}{l}\text { Vila do Corvo | Porto do } \\
\text { Boqueirão | Entre-marés }\end{array}$ & $\begin{array}{l}39,669523 \\
-31,112739\end{array}$ & Intertidal \\
\hline 9 & COR_VC_VCpbs & $\begin{array}{l}\text { Vila do } \\
\text { Corvo }\end{array}$ & $\begin{array}{l}\text { Vila do Corvo | Porto do } \\
\text { Boqueirão | Subtidal }\end{array}$ & $\begin{array}{l}39,668229 \\
-31,112482\end{array}$ & Subtidal \\
\hline
\end{tabular}

Sampling description: Intertidal collections were made during low tide by walking over the shores. Subtidal collections were made by SCUBA diving around the area. Sampling involved specimen collecting and species presence recording. For the former, at each location, samples were obtained by scraping from the surface one or two specimens of all the observed species and then placing them into labelled bags (Fig. 9). Species recording data was gathered by registering all species present in the sampled locations visited (Fig. 10).

Quality control: Each sampled taxon was identified by trained taxonomists and involved morphological and anatomical observations of whole specimens by eye and/or of 
histological preparations under microscopes to determine the main diagnostic features of each species, as described in literature.

Step description: Specimens were sorted and studied in the laboratory, following standard procedures used in macroalgae identification.

Species identification was usually based on a combination of morphological, anatomical and reproductive features. For small and simple thalli, this required observing the entire thallus with the unaided eye and/or using dissecting and compound microscopes. For larger and more complex algae, investigation of the thallus anatomy required histological procedures (longitudinal and transverse sections) or squashed preparations of mucilaginous thalli, sometimes after staining, to observe vegetative and reproductive structures and other diagnostic features.

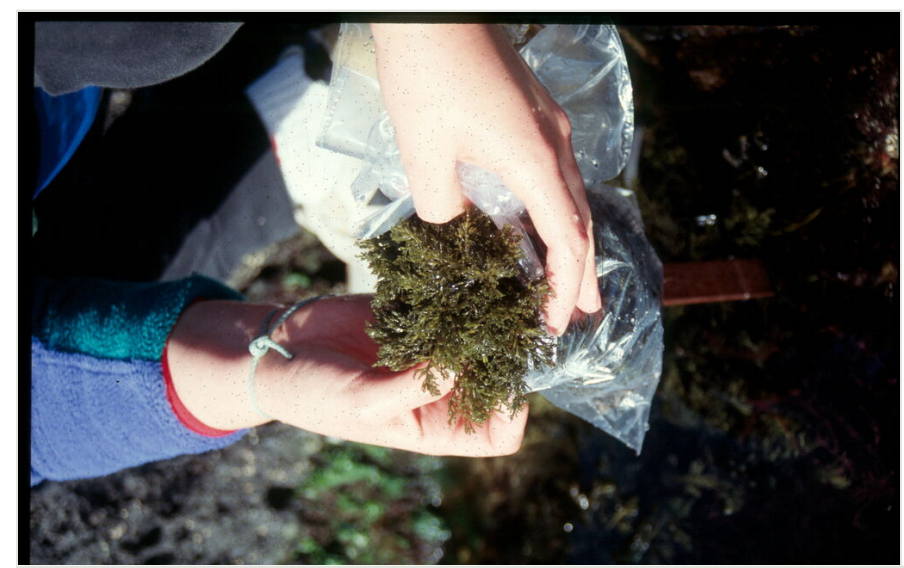

Figure 9. doi

Collecting macroalgae at the rocky intertidal (by the Island Aquatic Ecology Subgroup of cE3c$A B G)$.

The mixed nature of the Azorean algal flora with components from several geographical regions cause difficulties in species identification. Floras and keys for the North Atlantic, Tropical Atlantic and Western Mediterranean were used (e.g. Schmidt 1931, Taylor 1967, Taylor 1978, Levring 1974, Dixon and Irvine 1977, Lawson and John 1982, Irvine 1983, Gayral and Cosson 1986, Fletcher 1987, Afonso-Carrillo and Sansón 1989, Burrows 1991, Boudouresque et al. 1992, Cabioc'h et al. 1992, Maggs and Hommersand 1993, Irvine and Chamberlain 1994, Brodie et al. 2007, Lloréns et al. 2012, Rodríguez-Prieto et al. 2013).

For more critical and taxonomically-difficult taxa, specimens were taken to the Natural History Museum (London) for comparison with collections there.

A reference collection was made for all collected specimens by assigning them a herbarium code number and depositing them at the AZB Herbarium Ruy Telles Palhinha and the Molecular Systematics Laboratory, University of Azores. Depending on the species and on planned further research, different types of collections were made, namely (i) liquid 
collections using $5 \%$ buffered formaldehyde seawater and then replacing it by the fixing agent Kew (Bridsen and Forman 1999); (ii) dried collections, either by pressing the algae (most species) as described by Gayral and Cosson (1986) or by letting them air dry (calcareous species); and (iii) silica gel collections for molecular studies.

Nomenclatural and taxonomic status used here follow Algaebase (Guiry and Guiry 2020). The database was organised on FileMaker Pro.

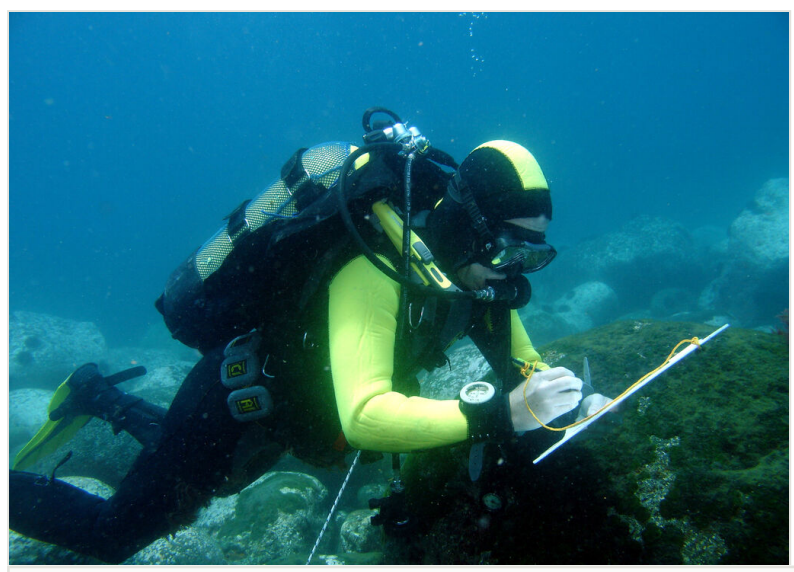

Figure 10. doi

Quantitative recording of the presence and coverage of macroalgal species at the subtidal rocky habitat (by the Island Aquatic Ecology Subgroup of cE3c-ABG).

\section{Geographic coverage}

Description: Flores Island Description: Azores, Portugal (approximately 39² $31^{\prime} 27^{\prime \prime} \mathrm{N}$, $\left.-31^{\circ} 15^{\prime} 31^{\prime \prime} \mathrm{W}\right)$

Coordinates: 39.524201 and 39.37521 Latitude; -31.258622 and -31.124496 Longitude.

Corvo Island Description: Azores, Portugal (approximately 3943'37"N, -31'44"W).

Coordinates: 39.726829 and 39.669576 Latitude; -31.12899 and -31.082546 Longitude.

\section{Taxonomic coverage}

Description: All macroalgae were identified to genus or species level. For Flores, a total of 196 taxa were identified belonging to 24 orders and 54 families, distributed in the phyla Rhodophyta (14 orders and 33 families), Chlorophyta (three orders and nine families) and Ochrophyta (seven orders and 12 families). For Corvo, a total of 56 taxa were identified belonging to 16 orders and 29 families, distributed in the phyla Rhodophyta (seven orders 
and 16 families), Chlorophyta (three orders and four families) and Ochrophyta (six orders and nine families).

\section{Temporal coverage}

Notes: The sampling was performed on several occasions between 1989 and 2018 .

\section{Collection data}

Collection name: AZB | Marine macroalgae collection of Flores and Corvo Islands (Azores)-Expedition Flores/89; AZB | Marine macroalgae collection of Flores and Corvo Islands (Azores)-Expedition Earthwatch Flores/95; AZB | Marine macroalgae collection of Flores and Corvo Islands (Azores)-Expedition Flores \& Corvo/99; Marine macroalgae collection of Flores and Corvo Islands (Azores)-Expedition Flores \& Corvo/2007; AZB I Marine macroalgae collection of Flores and Corvo Islands (Azores)-Occasional sampling; AZB | Marine macroalgae collection of Flores and Corvo Islands (Azores)-Occasional sampling; Marine macroalgae occurrence of Flores and Corvo Islands (Azores)-Expedition Flores \& Corvo/99; Marine macroalgae occurrence of Flores and Corvo Islands (Azores)Project MOST; Marine macroalgae occurrence of Flores and Corvo Islands (Azores)Campaign PIMA/BALA; Marine macroalgae occurrence of Flores and Corvo Islands (Azores)-Occasional sampling.

Collection identifier: 33967202-6b10-4182-99d2-621d594572cc; cd4c8dd8-49f7-4318-9b3d-c78aaec53c2d; 93772fb0-339a-4081-b742-a101ca66c019; a7ca4500-9608-44eb-9269-528a40264071; 1a7a0a41-5a5c-460c-815d-0c3503a5a2ea; cfc9d276-6d4e-4cc3-8f40-be9c3e5ba6e9; 434097ea-bac3-49ac-9f5a-3aa9b6c10503; db4e55cc-1401-4b1c-9343-fc2a3e27e473; 29ca7edc-3911-4c59-9722-c9aba69ca506; $153 \mathrm{bd} 328-1 \mathrm{e} 16-4 \mathrm{e} 9 \mathrm{e}-8 \mathrm{dc} 8-56994 \mathrm{c} 25 \mathrm{fb} 31$.

Parent collection identifier: AZB Herbarium Ruy Telles Palhinha, Faculty of Sciences and Technology of the University of the Azores; AZB Herbarium Ruy Telles Palhinha, Faculty of Sciences and Technology of the University of the Azores; AZB Herbarium Ruy Telles Palhinha, Faculty of Sciences and Technology of the University of the Azores; Expedition Flores \& Corvo/2007 Macroalgae collection, Faculty of Sciences and Technology of the University of the Azores; AZB Herbarium Ruy Telles Palhinha, Faculty of Sciences and Technology of the University of the Azores; AZB Herbarium Ruy Telles Palhinha, Faculty of Sciences and Technology of the University of the Azores; Not applicable; Not applicable; Not applicable; Not applicable.

Specimen preservation method: All specimens were preserved as follows: air dry, dried and pressed; liquid (formalin; fixing agent Kew), silica.

Curatorial unit: AZB Herbarium Ruy Telles Palhinha, Faculty of Sciences and Technology of the University of the Azores. 


\section{Usage licence}

Usage licence: Creative Commons Public Domain Waiver (CC-Zero)

\section{Data resources}

Data package title: Marine algal flora of Flores and Corvo Islands, Azores

Resource link: http://ipt.gbif.pt/ipt/resource?r=flores-corvo seaweed flora

Alternative identifiers: http://ipt.gbif.pt/ipt/resource?r=flores-corvo_seaweed_flora

Number of data sets: 1

Data set name: Marine algal flora of Flores and Corvo Islands, Azores

Character set: UTF-8

Download URL: http://ipt.gbif.pt/ipt/archive.do?r=flores-corvo seaweed flora

Data format: Darwin Core Archive

Data format version: 1.3

Description: This data paper presents physical and occurrence data from macroalgal surveys undertaken on Flores and Corvo Islands between 1989 and 2018 (Neto et al. 2020d). The dataset submitted to GBIF is structured as a sample event dataset, with two tables: event (as core) and occurrences. The data in this sampling event resource have been published as a Darwin Core Archive (DwCA), which is a standardised format for sharing biodiversity data as a set of one or more data tables. The core data table contains 90 records (eventID). The extension data table has 2077 occurrences. An extension record supplies extra information about a core record. The number of records in each extension data table is illustrated in the IPT link. This IPT archives the data and thus serves as the data repository. The data and resource metadata are available for downloading in the downloads section.

\begin{tabular}{|l|l|}
\hline Column label & Column description \\
\hline eventID & Identifier of the event, unique for the dataset \\
\hline country & Country of the sampling site \\
\hline countryCode & Code of the country where the event occurred \\
\hline stateProvince & Name of the region \\
\hline island & Name of the island \\
\hline municipality & Name of the municipality \\
\hline locality & Name of the locality \\
\hline
\end{tabular}




\begin{tabular}{|c|c|}
\hline locationID & Identifier of the location \\
\hline decimalLatitude & The geographic latitude of the sampling site \\
\hline decimalLongitude & The geographic longitud of the sampling site \\
\hline geodeticDatum & The spatial reference system upon which the geographic coordinates are based \\
\hline coordinateUncertaintylnMetres & $\begin{array}{l}\text { The horizontal distance (in metres) from the given decimalLatitude and } \\
\text { decimalLongitude describing the smallest circle containing the whole of the } \\
\text { Location }\end{array}$ \\
\hline eventDate & Time interval when the event occurred \\
\hline year & The year of the event \\
\hline samplingProtocol & Sampling method used during an event \\
\hline locationRemarks & Zonation level \\
\hline minimumDepthInMetres & The minimum depth in metres where the specimen was found \\
\hline maximumDepthInMetres & The maximum depth in metres where the specimen was found \\
\hline eventRemarks & Notes about the event \\
\hline occurrencelD & Identifier of the record, coded as a global unique identifier \\
\hline institutionID & $\begin{array}{l}\text { The identifier for the institution having custody of the object or information referred } \\
\text { to in the record }\end{array}$ \\
\hline institutionCode & $\begin{array}{l}\text { The acronym of the institution having custody of the object or information referred } \\
\text { to in the record }\end{array}$ \\
\hline collectionID & An identifier of the collection to which the record belongs \\
\hline collectionCode & The name of the collection from which the record was derived \\
\hline datasetName & The name identifying the dataset from which the record was derived \\
\hline eventID & Identifier of the event, unique for the dataset \\
\hline kingdom & Kingdom name \\
\hline phylum & Phylum name \\
\hline class & Class name \\
\hline order & Order name \\
\hline family & Family name \\
\hline genus & Genus name \\
\hline specificEpithet & The name of the first or species epithet of the scientificName \\
\hline infraspecificEpithet & $\begin{array}{l}\text { The name of the lowest or terminal infraspecific epithet of the scientificName, } \\
\text { excluding any rank designation }\end{array}$ \\
\hline acceptedNameUsage & The specimen accepted name, with authorship \\
\hline
\end{tabular}




\begin{tabular}{|l|l|}
\hline previousldentifications & Previous name of the specimen, with authorship \\
\hline scientificName & The name without authorship applied on the first identification of the specimen \\
\hline scientificNameAuthorship & $\begin{array}{l}\text { The authorship information for the scientificName formatted according to the } \\
\text { conventions of the applicable nomenclaturalCode }\end{array}$ \\
\hline taxonRank & The taxonomic rank of the most specific name in the scientificName \\
\hline basisOfRecord & The specific nature of the data record \\
\hline habitat & Description of the habitat where the specimen was found \\
\hline recordedBy & Person(s) responsible for sampling \\
\hline catalogNumber & Identifying code for a unique sample lot in a biological collection \\
\hline identifiedBy & Person(s) responsible for taxa identification \\
\hline type & The nature of the resource \\
\hline preparations & The preservation method used for the specimen \\
\hline establishmentMeans & The establishment status of the organism in the study region \\
\hline occurrenceRemarks & New record status assignment \\
\hline license & Reference to the licence under which the record is published \\
\hline
\end{tabular}

\section{Additional information}

This paper accommodates the 1687 specimens of macroalgae recorded from Flores Island in 196 taxa comprising 128 confirmed species and 68 taxa identified only to generic level. The confirmed species (Tables 4, 5) include 80 Rhodophyta, 22 Chlorophyta and 26 Ochrophyta (Phaeophyceae). Of these, 37 species are newly recorded for the Island (20 Rhodophyta, six Chlorophyta and 11 Ochrophyta). Most species are native, including the two Macaronesian endemics (Laurencia viridis and Millerella tinerfensis. Six species are introductions to the algal flora (the Rhodophyta Asparagopsis armata, Neoizziella divaricata and Symphyocladia marchantioides; the Chlorophyta Codium fragile subsp. fragile; and the Ochrophyta Hydroclathrus tilesii and Papenfussiella kuromo). Fourteen species are uncertain in status (10 Rhodophyta, two Chlorophyta and two Ochrophyta).

Many species were only sporadically recorded on Flores, but 19 were commonly found around the Island and occurred quite abundantly in some locations, namely: the Rhodophyta Acrosorium ciliolatum (Harvey) Kylin, Asparagopsis armata, A. taxiformis (Delile) Trevisan, Platoma cyclocolpum (Montagne) F.Schmitz, Plocamium cartilagineum (Linnaeus) P.S.Dixon, Pterocladiella capillacea and Sphaerococcus coronopifolius Stackhouse; the Chlorophyta Anadyomene stellata (Wulfen) C.Agardh, Cladophora prolifera (Roth) Kützing, Codium adhaerens C.Agradh, Microdictyon umbilicatum (Velley) Zanardiniand Ulva rigida C.Agardh; and the Ochrophyta Cladostephus spongiosus (Hudson) C.Agardh, Colpomenia sinuosa (Mertens ex Roth) Derbès \& Solier in Castagne, 
Halopteris filicina, Halopteris scoparia (Linnaeus) Sauvageau, Padina pavonica (Linnaeus) Thivy, Zanardinia typus (Nardo) P.C.Silva and Zonaria tournefortii.

Table 4.

Macroalgal species recorded from Flores Island, with information on relative abundance, origin and status.

\begin{tabular}{|c|c|c|c|c|}
\hline Phylum & Species (Accepted Name) & $\begin{array}{l}\text { Number } \\
\text { of records }\end{array}$ & $\begin{array}{l}\text { Establishment } \\
\text { Means }\end{array}$ & OccurrenceRemarks \\
\hline Chlorophyta & Anadyomene stellata (Wulfen) C.Agardh & 13 & Uncertain & \\
\hline Chlorophyta & Bryopsis cupressina J.V.Lamouroux & 2 & Native & New record \\
\hline Chlorophyta & Bryopsis hypnoides J.V.Lamouroux & 4 & Native & \\
\hline Chlorophyta & Bryopsis pennata J.V.Lamouroux & 1 & Native & \\
\hline Chlorophyta & Bryopsis plumosa (Hudson) C. Agardh & 3 & Native & \\
\hline Chlorophyta & Chaetomorpha aerea (Dillwyn) Kützing & 1 & Native & \\
\hline Chlorophyta & Cladophora albida (Nees) Kützing & 3 & Native & \\
\hline Chlorophyta & Cladophora coelothrix Kützing & 6 & Native & \\
\hline Chlorophyta & Cladophora hutchinsiae (Dillwyn) Kützing & 2 & Native & New record \\
\hline Chlorophyta & $\begin{array}{l}\text { Cladophora lehmanniana (Lindenberg) } \\
\text { Kützing }\end{array}$ & 5 & Native & New record \\
\hline Chlorophyta & Cladophora prolifera (Roth) Kützing & 20 & Native & \\
\hline Chlorophyta & $\begin{array}{l}\text { Cladophoropsis membranacea (Hofman } \\
\text { Bang ex C.Agardh) Børgesen }\end{array}$ & 1 & Uncertain & \\
\hline Chlorophyta & Codium adhaerens C.Agardh & 18 & Native & \\
\hline Chlorophyta & Codium decorticatum (Woodward) M.A.Howe & 3 & Native & New record \\
\hline Chlorophyta & $\begin{array}{l}\text { Codium fragile subsp. fragile (Suringar) } \\
\text { Hariot }\end{array}$ & 5 & Introduced & New record \\
\hline Chlorophyta & Derbesia marina (Lyngbye) Solier & 1 & Native & \\
\hline Chlorophyta & Lychaete pellucida (Hudson) M.J.Wynne & 4 & Native & New record \\
\hline Chlorophyta & Microdictyon umbilicatum (Velley) Zanardini & 31 & Native & \\
\hline Chlorophyta & Ulva clathrata (Roth) C.Agardh & 3 & Native & \\
\hline Chlorophyta & Ulva intestinalis Linnaeus & 8 & Native & \\
\hline Chlorophyta & Ulva rigida C.Agardh & 10 & Native & \\
\hline Chlorophyta & Valonia utricularis (Roth) C.Agardh & 3 & Native & \\
\hline Ochrophyta & Ascophyllum nodosum (Linnaeus) Le Jolis & 7 & Native & \\
\hline Ochrophyta & Carpomitra costata (Stackhouse) Batters & 2 & Native & \\
\hline Ochrophyta & $\begin{array}{l}\text { Cladostephus spongiosus (Hudson) } \\
\text { C.Agardh }\end{array}$ & 23 & Native & \\
\hline
\end{tabular}




\begin{tabular}{|c|c|c|c|c|}
\hline Phylum & Species (Accepted Name) & $\begin{array}{l}\text { Number } \\
\text { of records }\end{array}$ & $\begin{array}{l}\text { Establishment } \\
\text { Means }\end{array}$ & OccurrenceRemarks \\
\hline Ochrophyta & $\begin{array}{l}\text { Colpomenia sinuosa (Mertens ex Roth) } \\
\text { Derbès \& Solier }\end{array}$ & 61 & Native & \\
\hline Ochrophyta & Cutleria multifida (Turner) Greville & 4 & Uncertain & \\
\hline Ochrophyta & $\begin{array}{l}\text { Cutleria multifida (Turner) Grevill, phase } \\
\text { Aglaozonia parvula (Greville) Zanardini }\end{array}$ & 2 & Uncertain & New record \\
\hline Ochrophyta & Cystoseira foeniculacea (Linnaeus) Greville & 4 & Native & \\
\hline Ochrophyta & Cystoseira humilis Schousboe ex Kützing & 1 & Native & \\
\hline Ochrophyta & $\begin{array}{l}\text { Dictyopteris polypodioides (A.P.De Candolle) } \\
\text { J.V.Lamouroux }\end{array}$ & 2 & Native & New record \\
\hline Ochrophyta & Dictyota bartayresiana J.V.Lamouroux & 4 & Native & \\
\hline Ochrophyta & $\begin{array}{l}\text { Dictyota cyanoloma Tronholm, De Clerck, } \\
\text { A.Gómez-Garreta \& Rull Lluch }\end{array}$ & 1 & Native & New record \\
\hline Ochrophyta & Dictyota dichotoma (Hudson) J.V.Lamouroux & 3 & Native & \\
\hline Ochrophyta & Halopteris filicina (Grateloup) Kützing & 54 & Native & \\
\hline Ochrophyta & Halopteris scoparia (Linnaeus) Sauvageau & 61 & Native & \\
\hline Ochrophyta & $\begin{array}{l}\text { Hydroclathrus tilesii (Endlicher) Santiañez \& } \\
\text { M.J.Wynne }\end{array}$ & 1 & Introduced & New record \\
\hline Ochrophyta & Leathesia marina (Lyngbye) Decaisne & 6 & Uncertain & \\
\hline Ochrophyta & $\begin{array}{l}\text { Lobophora variegata (J.V.Lamouroux) } \\
\text { Womersley ex E.C.Oliveira }\end{array}$ & 11 & Native & New record \\
\hline Ochrophyta & Myrionema strangulans Greville & 1 & Native & \\
\hline Ochrophyta & Padina pavonica (Linnaeus) Thivy & 85 & Native & \\
\hline Ochrophyta & Papenfussiella kuromo (Yendo) Inagaki & 1 & Introduced & New record \\
\hline Ochrophyta & $\begin{array}{l}\text { Petrospongium berkeleyi (Greville) Nägeli ex } \\
\text { Kützing }\end{array}$ & 1 & Native & New record \\
\hline Ochrophyta & Sargassum furcatum Kützing & 5 & Native & New record \\
\hline Ochrophyta & Sargassum vulgare C.Agardh, nom. illeg. & 5 & Native & \\
\hline Ochrophyta & Sphacelaria cirrosa (Roth) C.Agardh & 1 & Native & New record \\
\hline Ochrophyta & Taonia atomaria (Woodward) J.Agardh & 6 & Native & New record \\
\hline Ochrophyta & Zanardinia typus (Nardo) P.C.Silva & 15 & Native & New record \\
\hline Ochrophyta & $\begin{array}{l}\text { Zonaria tournefortii (J.V.Lamouroux) } \\
\text { Montagne }\end{array}$ & 96 & Native & \\
\hline Rhodophya & Acrosorium ciliolatum (Harvey) Kylin & 35 & Native & \\
\hline Rhodophya & Amphiroa beauvoisii J.V.Lamouroux & 1 & Native & \\
\hline Rhodophya & Amphiroa rigida J.V.Lamouroux & 5 & Native & \\
\hline Rhodophya & Asparagopsis armata Harvey & 58 & Introduced & \\
\hline
\end{tabular}




\begin{tabular}{|c|c|c|c|c|}
\hline Phylum & Species (Accepted Name) & $\begin{array}{l}\text { Number } \\
\text { of records }\end{array}$ & $\begin{array}{l}\text { Establishment } \\
\text { Means }\end{array}$ & OccurrenceRemarks \\
\hline Rhodophya & $\begin{array}{l}\text { Asparagopsis armata Harvey, phase } \\
\text { Falkenbergia rufolanosa (Harvey) F.Schmitz }\end{array}$ & 6 & Introduced & \\
\hline Rhodophya & Asparagopsis taxiformis (Delile) Trevisan & 38 & Native & \\
\hline Rhodophya & Bornetia secundiflora (J.Agardh) Thuret & 2 & Native & \\
\hline Rhodophya & Botryocladia botryoides (Wulfen) Feldmann & 8 & Native & New record \\
\hline Rhodophya & $\begin{array}{l}\text { Callithamnion corymbosum (J.E.Smith) } \\
\text { Lyngbye }\end{array}$ & 3 & Native & \\
\hline Rhodophya & $\begin{array}{l}\text { Callithamnion granulatum (Ducluzeau) } \\
\text { C.Agardh }\end{array}$ & 2 & Native & New record \\
\hline Rhodophya & Caulacanthus ustulatus (Turner) Kützing & 2 & Uncertain & \\
\hline Rhodophya & $\begin{array}{l}\text { Centroceras clavulatum (C.Agardh) } \\
\text { Montagne }\end{array}$ & 14 & Native & \\
\hline Rhodophya & Ceramium ciliatum (J.Ellis) Ducluzeau & 2 & Native & \\
\hline Rhodophya & Ceramium cimbricum H.E.Petersen & 3 & Native & \\
\hline Rhodophya & Ceramium derbesii Solier ex Kützing & 2 & Native & \\
\hline Rhodophya & Ceramium echionotum J.Agardh & 1 & Native & New record \\
\hline Rhodophya & Ceramium gaditanum (Clemente) Cremades & 2 & Uncertain & \\
\hline Rhodophya & Ceramium virgatum Roth & 3 & Native & \\
\hline Rhodophya & $\begin{array}{l}\text { Ceratodictyon intricatum (C.Agardh) } \\
\text { R.E.Norris }\end{array}$ & 2 & Native & \\
\hline Rhodophya & $\begin{array}{l}\text { Ceratodictyon scoparium (Montagne \& } \\
\text { Millardet) R.E.Norris }\end{array}$ & 1 & Uncertain & New record \\
\hline Rhodophya & Chondracanthus acicularis (Roth) Fredericq & 11 & Native & \\
\hline Rhodophya & $\begin{array}{l}\text { Chondracanthus teedei (Mertens ex Roth) } \\
\text { Kützing }\end{array}$ & 1 & Native & New record \\
\hline Rhodophya & Chondria dasyphylla (Woodward) C.Agardh & 6 & Uncertain & \\
\hline Rhodophya & $\begin{array}{l}\text { Corallina ferreyrae E.Y.Dawson, Acleto \& } \\
\text { Foldvik }\end{array}$ & 7 & Native & New record \\
\hline Rhodophya & Corallina officinalis Linnaeus & 18 & Native & \\
\hline Rhodophya & Cruoria pellita (Lyngbye) Fries & 1 & Native & \\
\hline Rhodophya & Cryptopleura ramosa (Hudson) L.Newton & 2 & Native & New record \\
\hline Rhodophya & $\begin{array}{l}\text { Ellisolandia elongata (J.Ellis \& Solander) } \\
\text { K.R.Hind \& G.W.Saunders }\end{array}$ & 3 & Native & \\
\hline Rhodophya & $\begin{array}{l}\text { Erythrocystis montagnei (Derbès \& Solier) } \\
\text { P.C.Silva }\end{array}$ & 2 & Native & New record \\
\hline Rhodophya & Gelidium corneum (Hudson) J.V.Lamouroux & 10 & Native & \\
\hline
\end{tabular}




\begin{tabular}{|c|c|c|c|c|}
\hline Phylum & Species (Accepted Name) & $\begin{array}{l}\text { Number } \\
\text { of records }\end{array}$ & $\begin{array}{l}\text { Establishment } \\
\text { Means }\end{array}$ & OccurrenceRemarks \\
\hline Rhodophya & Gelidium microdon Kützing & 4 & Native & \\
\hline Rhodophya & Gelidium pusillum (Stackhouse) Le Jolis & 12 & Native & \\
\hline Rhodophya & Gelidium spinosum (S.G.Gmelin) P.C.Silva & 11 & Native & \\
\hline Rhodophya & Gigartina pistillata (S.G.Gmelin) Stackhouse & 1 & Native & \\
\hline Rhodophya & $\begin{array}{l}\text { Gracilariopsis longissima (S.G.Gmelin) } \\
\text { Steentoft, L.M.Irvine \& Farnham }\end{array}$ & 2 & Native & \\
\hline Rhodophya & $\begin{array}{l}\text { Grateloupia filicina (J.V.Lamouroux) } \\
\text { C.Agardh }\end{array}$ & 10 & Native & \\
\hline Rhodophya & Griffithsia corallinoides (Linnaeus) Trevisan & 1 & Uncertain & \\
\hline Rhodophya & Griffithsia devoniensis Harvey & 1 & Native & New record \\
\hline Rhodophya & Gymnogongrus crenulatus (Turner) J.Agardh & 14 & Native & \\
\hline Rhodophya & Gymnogongrus griffithsiae (Turner) C.Martius & 3 & Native & \\
\hline Rhodophya & $\begin{array}{l}\text { Gymnothamnion elegans (Schousboe ex } \\
\text { C.Agardh) J.Agardh }\end{array}$ & 2 & Native & \\
\hline Rhodophya & $\begin{array}{l}\text { Halurus flosculosus (J.Ellis) Maggs \& } \\
\text { Hommersand }\end{array}$ & 1 & Native & \\
\hline Rhodophya & Hypnea musciformis (Wulfen) J.V.Lamouroux & 19 & Uncertain & \\
\hline Rhodophya & $\begin{array}{l}\text { Hypoglossum hypoglossoides (Stackhouse) } \\
\text { Collins \& Hervey }\end{array}$ & 9 & Native & New record \\
\hline Rhodophya & Jania capillacea Harvey & 1 & Native & New record \\
\hline Rhodophya & Jania crassa J.V.Lamouroux & 2 & Native & New record \\
\hline Rhodophya & Jania longifurca Zanardini & 8 & Uncertain & \\
\hline Rhodophya & Jania rubens (Linnaeus) J.V.Lamouroux & 6 & Native & \\
\hline Rhodophya & Jania virgata (Zanardini) Montagne & 13 & Uncertain & \\
\hline Rhodophya & Kallymenia reniformis (Turner) J.G.Agardh & 1 & Native & \\
\hline Rhodophya & Laurencia obtusa (Huds.) J.V.Lamouroux & 8 & Native & \\
\hline Rhodophya & Laurencia viridis Gil-Rodríguez \& Haroun & 3 & $\begin{array}{l}\text { Macaronesian } \\
\text { endemism }\end{array}$ & New record \\
\hline Rhodophya & $\begin{array}{l}\text { Laurenciella marilzae (Gil-Rodríguez, } \\
\text { Sentíes, Díaz-Larrea, Cassano \& M.T.Fujii) } \\
\text { Gil-Rodríguez, Sentíes, Díaz-Larrea, } \\
\text { Cassano \& M.T.Fujii }\end{array}$ & 4 & Native & New record \\
\hline Rhodophya & $\begin{array}{l}\text { Leptosiphonia fibrillosa (Agardh) A.M.Savoie } \\
\text { \& G.W.Saunders }\end{array}$ & 1 & Native & \\
\hline Rhodophya & Lomentaria articulata (Hudson) Lyngbye & 12 & Native & \\
\hline Rhodophya & $\begin{array}{l}\text { Mesophyllum expansum (Philippi) Cabioch \& } \\
\text { M.L.Mendoza }\end{array}$ & 1 & Native & New record \\
\hline
\end{tabular}




\begin{tabular}{|c|c|c|c|c|}
\hline Phylum & Species (Accepted Name) & $\begin{array}{l}\text { Number } \\
\text { of records }\end{array}$ & $\begin{array}{l}\text { Establishment } \\
\text { Means }\end{array}$ & OccurrenceRemarks \\
\hline Rhodophya & $\begin{array}{l}\text { Millerella tinerfensis (Seoane-Camba) } \\
\text { S.M.Boo \& J.M.Rico }\end{array}$ & 3 & $\begin{array}{l}\text { Macaronesian } \\
\text { endemism }\end{array}$ & \\
\hline Rhodophya & Nemalion elminthoides (Velley) Batters & 5 & Native & \\
\hline Rhodophya & $\begin{array}{l}\text { Neoizziella divaricata (C.K.Tseng) S.-M.Lin, } \\
\text { S.-Y.Yang \& Huisman }\end{array}$ & 5 & Introduced & New record \\
\hline Rhodophya & $\begin{array}{l}\text { Osmundea hybrida (A.P.de Candolle) } \\
\text { K.W.Nam }\end{array}$ & 4 & Native & \\
\hline Rhodophya & Osmundea pinnatifida (Hudson) Stackhouse & 10 & Native & \\
\hline Rhodophya & $\begin{array}{l}\text { Peyssonnelia squamaria (S.G.Gmelin) } \\
\text { Decaisne ex J.Agardh }\end{array}$ & 6 & Native & \\
\hline Rhodophya & Phyllophora crispa (Hudson) P.S.Dixon & 3 & Native & \\
\hline Rhodophya & Platoma cyclocolpum (Montagne) F.Schmitz & 42 & Native & New record \\
\hline Rhodophya & $\begin{array}{l}\text { Plocamium cartilagineum (Linnaeus) } \\
\text { P.S.Dixon }\end{array}$ & 23 & Native & \\
\hline Rhodophya & $\begin{array}{l}\text { Polysiphonia opaca (C.Agardh) Moris \& De } \\
\text { Notaris }\end{array}$ & 2 & Native & \\
\hline Rhodophya & $\begin{array}{l}\text { Polysiphonia stricta (Mertens ex Dillwyn) } \\
\text { Greville }\end{array}$ & 1 & Native & \\
\hline Rhodophya & $\begin{array}{l}\text { Pterocladiella capillacea (S.G.Gmelin) } \\
\text { Santelices \& Hommersand }\end{array}$ & 42 & Native & \\
\hline Rhodophya & Rhodymenia holmesii Ardissone & 14 & Native & \\
\hline Rhodophya & $\begin{array}{l}\text { Schimmelmannia schousboei (J.Agardh) } \\
\text { J.Agardh }\end{array}$ & 1 & Native & \\
\hline Rhodophya & Schizymenia apoda (J.Agardh) J.Agardh & 1 & Native & New record \\
\hline Rhodophya & $\begin{array}{l}\text { Schottera nicaeensis (J.V.Lamouroux ex } \\
\text { Duby) Guiry \& Hollenberg }\end{array}$ & 2 & Uncertain & \\
\hline Rhodophya & Sphaerococcus coronopifolius Stackhouse & 20 & Native & \\
\hline Rhodophya & Spyridia filamentosa (Wulfen) Harvey & 3 & Native & \\
\hline Rhodophya & $\begin{array}{l}\text { Stenogramma interruptum (C.Agardh) } \\
\text { Montagne }\end{array}$ & 1 & Native & \\
\hline Rhodophya & $\begin{array}{l}\text { Symphyocladia marchantioides (Harvey) } \\
\text { Falkenberg }\end{array}$ & 1 & Introduced & \\
\hline Rhodophya & Taenioma nanum (Kützing) Papenfuss & 1 & Native & New record \\
\hline Rhodophya & Tenarea tortuosa (Esper) Me.Lemoine & 1 & Native & \\
\hline Rhodophya & Vertebrata fruticulosa (Wulfen) Kuntze & 2 & Native & \\
\hline Rhodophya & Vertebrata fucoides (Hudson) Kuntze & 2 & Uncertain & \\
\hline Rhodophya & Vertebrata thuyoides (Harvey) Kuntze & 1 & Native & New record \\
\hline
\end{tabular}


For the Island of Corvo, this paper accommodates the 390 specimens of macroalgae recorded in 56 taxa comprising 43 confirmed species and 13 taxa identified only to genus level. The confirmed species (Tables 6,7 ) include 22 Rhodophyta, eight Chlorophyta and 13 Ochrophyta (Phaeophyceae). Of these, 22 species are newly recorded to the Island (nine Rhodophyta, four Chlorophyta and nine Ochrophyta). Most species are native, two represent introductions to the algal flora of the Azores (the Rhodophyta Asparagopsis armata and the Chlorophyta Codium fragile subsp. fragile) and seven have an uncertain status (five Rhodophyta and two Ochrophyta).

Table 5.

Summary of the macroalgal flora of Flores Island, with information on the species origins and status.

\begin{tabular}{|l|l|l|l|l|l|l|l|l|l|l|}
\hline Phyllum & Order & Family & $\begin{array}{l}\text { Specimens } \\
\text { Number }\end{array}$ & $\begin{array}{l}\text { Total } \\
\text { taxa }\end{array}$ & $\begin{array}{l}\text { Total } \\
\text { species }\end{array}$ & Native & Introduced & Uncertain & $\begin{array}{l}\text { Macaronesian } \\
\text { endemism }\end{array}$ & $\begin{array}{l}\text { New } \\
\text { record }\end{array}$ \\
\hline Rhodophyta & 14 & 33 & 789 & 120 & 80 & 65 & 3 & 10 & 2 & 20 \\
\hline Chlorophyta & 3 & 9 & 216 & 35 & 22 & 19 & 1 & 2 & 6 \\
\hline Ochrophyta & 7 & 12 & 682 & 41 & 26 & 22 & 2 & 2 & 11 \\
\hline Total & 24 & 54 & 1687 & 196 & 128 & 106 & 6 & 14 & 2 & 37 \\
\hline
\end{tabular}

Table 6.

Macroagal species recorded from Corvo Island, with information on relative abundance, origin and status.

\begin{tabular}{|l|l|l|l|l|}
\hline Phylum & Species (Accepted Name) & $\begin{array}{l}\text { Number of } \\
\text { records }\end{array}$ & $\begin{array}{l}\text { Establishment } \\
\text { Means }\end{array}$ & OccurrenceRemarks \\
\hline Chlorophyta & Chaetomorpha linum (O.F.Müller) Kützing & 1 & Native & \\
\hline Chlorophyta & Cladophora coelothrix Kützing & 1 & Native & New record \\
\hline Chlorophyta & Cladophora hutchinsiae (Dillwyn) Kützing & 1 & Native & \\
\hline Chlorophyta & Cladophora laetevirens (Dillwyn) Kützing & 1 & Uncertain & \\
\hline Chlorophyta & Cladophora prolifera (Roth) Kützing & 2 & Native & \\
\hline Chlorophyta & $\begin{array}{l}\text { Codium fragile subsp. fragile (Suringar) } \\
\text { Hariot }\end{array}$ & 2 & Introduced & New record \\
\hline Chlorophyta & $\begin{array}{l}\text { Microdictyon umbilicatum (Velley) } \\
\text { Zanardini }\end{array}$ & 29 & Native & \\
\hline Chlorophyta & Valonia utricularis (Roth) C.Agardh & 1 & Native & New record \\
\hline Ochrophyta & Carpomitra costata (Stackhouse) Batters & 1 & Native & New record \\
\hline Ochrophyta & $\begin{array}{l}\text { Cladostephus spongiosus (Hudson) } \\
\text { C.Agardh }\end{array}$ & 1 & Native & \\
\hline
\end{tabular}




\begin{tabular}{|c|c|c|c|c|}
\hline Phylum & Species (Accepted Name) & $\begin{array}{l}\text { Number of } \\
\text { records }\end{array}$ & $\begin{array}{l}\text { Establishment } \\
\text { Means }\end{array}$ & OccurrenceRemarks \\
\hline Ochrophyta & $\begin{array}{l}\text { Colpomenia sinuosa (Mertens ex Roth) } \\
\text { Derbès \& Solier }\end{array}$ & 18 & Native & \\
\hline Ochrophyta & Cutleria multifida (Turner) Greville & 3 & Uncertain & New record \\
\hline Ochrophyta & $\begin{array}{l}\text { Dictyopteris polypodioides (A.P.De } \\
\text { Candolle) J.V.Lamouroux }\end{array}$ & 3 & Native & New record \\
\hline Ochrophyta & Halopteris filicina (Grateloup) Kützing & 31 & Native & New record \\
\hline Ochrophyta & Halopteris scoparia (Linnaeus) Sauvageau & 15 & Native & \\
\hline Ochrophyta & Leathesia marina (Lyngbye) Decaisne & 1 & Uncertain & New record \\
\hline Ochrophyta & $\begin{array}{l}\text { Lobophora variegata (J.V.Lamouroux) } \\
\text { Womersley ex E.C.Oliveira }\end{array}$ & 8 & Native & New record \\
\hline Ochrophyta & Padina pavonica (Linnaeus) Thivy & 32 & Native & \\
\hline Ochrophyta & Sargassum furcatum Kützing & 2 & Native & New record \\
\hline Ochrophyta & Taonia atomaria (Woodward) J.Agardh & 5 & Native & New record \\
\hline Ochrophyta & $\begin{array}{l}\text { Zonaria tournefortii (J.V.Lamouroux) } \\
\text { Montagne }\end{array}$ & 33 & Native & \\
\hline Rhodophyta & Acrosorium ciliolatum (Harvey) Kylin & 28 & Native & New record \\
\hline Rhodophyta & Asparagopsis armata Harvey & 23 & Introduced & \\
\hline Rhodophya & $\begin{array}{l}\text { Asparagopsis armata Harvey, phase } \\
\text { Falkenbergia rufolanosa (Harvey) } \\
\text { F.Schmitz }\end{array}$ & 1 & Introduced & \\
\hline Rhodophyta & Asparagopsis taxiformis (Delile) Trevisan & 13 & Native & New record \\
\hline Rhodophyta & $\begin{array}{l}\text { Carradoriella denudata (Dillwyn) } \\
\text { A.M.Savoie \& G.W.Saunders }\end{array}$ & 1 & Uncertain & \\
\hline Rhodophyta & $\begin{array}{l}\text { Caulacanthus ustulatus (Mertens ex } \\
\text { Turner) Kützing }\end{array}$ & 1 & Uncertain & New record \\
\hline Rhodophyta & $\begin{array}{l}\text { Chondracanthus acicularis (Roth) } \\
\text { Fredericq }\end{array}$ & 2 & Native & \\
\hline Rhodophyta & Chondria capillaris (Hudson) M.J.Wynne & 1 & Native & \\
\hline Rhodophyta & Corallina officinalis Linnaeus & 3 & Native & \\
\hline Rhodophyta & $\begin{array}{l}\text { Erythrodermis traillii (Holmes ex Batters) } \\
\text { Guiry \& Garbary }\end{array}$ & 1 & Uncertain & \\
\hline Rhodophyta & Gelidium pusillum (Stackhouse) Le Jolis & 2 & Native & \\
\hline Rhodophyta & $\begin{array}{l}\text { Gigartina pistillata (S.G.Gmelin) } \\
\text { Stackhouse }\end{array}$ & 1 & Native & \\
\hline Rhodophyta & $\begin{array}{l}\text { Gymnogongrus crenulatus (Turner) } \\
\text { J.Agardh }\end{array}$ & 1 & Native & New record \\
\hline Rhodophyta & $\begin{array}{l}\text { Gymnogongrus griffithsiae (Turner) } \\
\text { C.Martius }\end{array}$ & 5 & Native & New record \\
\hline
\end{tabular}




\begin{tabular}{|c|c|c|c|c|}
\hline Phylum & Species (Accepted Name) & $\begin{array}{l}\text { Number of } \\
\text { records }\end{array}$ & $\begin{array}{l}\text { Establishment } \\
\text { Means }\end{array}$ & OccurrenceRemarks \\
\hline Rhodophyta & Jania virgata (Zanardini) Montagne & 8 & Uncertain & New record \\
\hline Rhodophyta & Nemalion elminthoides (Velley) Batters & 1 & Native & \\
\hline Rhodophyta & $\begin{array}{l}\text { Osmundea pinnatifida (Hudson) } \\
\text { Stackhouse }\end{array}$ & 2 & Native & \\
\hline Rhodophyta & $\begin{array}{l}\text { Plocamium cartilagineum (Linnaeus) } \\
\text { P.S.Dixon }\end{array}$ & 4 & Native & New record \\
\hline Rhodophyta & $\begin{array}{l}\text { Pterocladiella capillacea (S.G.Gmelin) } \\
\text { Santelices \& Hommersand }\end{array}$ & 6 & Native & \\
\hline Rhodophyta & $\begin{array}{l}\text { Schottera nicaeensis (J.V.Lamouroux ex } \\
\text { Duby) Guiry \& Hollenberg }\end{array}$ & 1 & Uncertain & \\
\hline Rhodophyta & Sphaerococcus coronopifolius Stackhouse & 3 & Native & New record \\
\hline Rhodophyta & Spyridia filamentosa (Wulfen) Harvey & 2 & Native & New record \\
\hline Rhodophyta & Vertebrata fruticulosa (Wulfen) Kuntze & 1 & Native & \\
\hline
\end{tabular}

Table 7.

Summary of the macroalgal flora of Corvo Island, with information on the species origins and status.

\begin{tabular}{|l|l|l|l|l|l|l|l|l|l|}
\hline Phyllum & Order & Family & $\begin{array}{l}\text { Specimens } \\
\text { Number }\end{array}$ & $\begin{array}{l}\text { Total } \\
\text { taxa }\end{array}$ & $\begin{array}{l}\text { Total } \\
\text { species }\end{array}$ & Native & Introduced & Uncertain & $\begin{array}{l}\text { New } \\
\text { record }\end{array}$ \\
\hline Rhodophyta & 7 & 16 & 136 & 30 & 22 & 16 & 1 & 5 & 9 \\
\hline Chlorophyta & 3 & 4 & 42 & 9 & 8 & 7 & 1 & 0 & 4 \\
\hline Ochrophyta & 6 & 9 & 212 & 17 & 13 & 11 & 0 & 2 & 9 \\
\hline Total & 16 & 29 & 390 & 56 & 43 & 34 & 2 & 7 & 22 \\
\hline
\end{tabular}

Nine species were commonly found, some abundantly in some locations, namely: the Rhodophyta Acrosorium ciliolatum, Asparagopsis armata, A. taxiformis; the Chlorophyta Microdictyon umbilicatum; and the Ochrophyta Colpomenia sinuosa, Halopteris filicina, $\mathrm{H}$. scoparia, Padina pavonica and Zonaria tournefortii.

A mismatch regarding the GBIF backbone taxonomy of some of the macroalgae species names was identified as detailed in Suppl. material 1.

\section{Acknowledgements}

This paper is the result of several projects, expeditions and campaigns (see Funding above) and is supported by the project "ACORES-01-0145-FEDER-000072" as part of the Operational Programme Azores 2020 (85\% ERDF and 15\% regional funds). We are grateful to the Municipalities of Lajes and Santa Cruz das Flores, the Ecoteca of Flores, the 
Basic and Secondary School of Santa Cruz das Flores and the Flores Forestry Services for their logistic support during the Expeditions and Campaigns. Thanks are due to the many Campaign teams for their critical involvement in this project (the international Earthwatch team, Carolina Arruda, Cláudia Hipólito, Cristiana Figueiredo, Heather Baldwin, Inês Neto, Isabel Pinto, Joana Micael, Marco Henrique, Maria Ana Dionísio, Maria Ventura, Nuno Vaz Álvaro, Patrícia Madeira, Pedro Alves, Pedro Cerqueira, Rita Grilo, Rita Norberto, Rui Santos and Sandra Monteiro). Manuela I. Parente was supported by a Postdoc grant (SFRH/BPD/34246/2006) awarded by Fundação para a Ciência e a Tecnologia (FCT). Afonso Prestes was supported by a PhD grant (M3.1.a/F/083/2015) awarded by Fundo Regional da Ciência e Tecnologia (FRCT). WF was awarded grants from the British Council and Earthwatch.

\section{Author contributions}

- AIN: Conceptualization; Methodology; Research (field and laboratory work); Resources; Data Curation; Formal analysis and interpretation; Paper writing

- MIP: Research (field and laboratory work); Data Curation; Formal analysis and interpretation; Paper writing

- $\quad$ IT: Methodology; Research (field work and laboratory work); Data Curation; Paper writing

- $\quad$ RF: Methodology; Research (field work and laboratory work); Data Curation

- WF: Methodology; Research (field work and laboratory work); Data Curation

- $\quad$ ACC: Research (field and laboratory work); Resources; Data Curation

- $\quad$ AZB: Research (field and laboratory work); Data Curation

- $\quad$ SM: Research (field and laboratory work); Data Curation

- RR: Resources; Data Curation

- PA: Resources

- $\quad$ ACLP: Investigation (laboratory work); Resources; Paper writing

- $\quad$ NVA: Research (field work); Maps elaboration

- DM-F: Research (field and laboratory work); Data Curation

- $\quad$ RMAN: Data Curation; Formal analysis and interpretation; Paper writing

- JMNA: Research (field work and laboratory work); Formal analysis and interpretation; Paper writing

- IM: Data Curation; Formal analysis and interpretation; Paper writing

\section{References}

- Afonso-Carrillo J, Sansón M (1989) Clave llustrada para la Determinación de los Macrófitos Marinas Bentónicos de las Islas Canarias. [lllustrated key for the determination of the Benthic Marine Macrophytes of the Canary Islands]. Departamento de Biologia Vegetal (Botânica), Universidad de La Laguna, La Laguna, 55 pp. 
- $\quad$ Azevedo JM, Neto Al, Costa AC (1990) Estudo de impacte ambiental sobre o meio marinho das infraestruturas de transporte das ilhas das Flores e Corvo. Departamento de Biologia, Universidade dos Açores.

- $\quad$ Azevedo JM (1998) Depósitos vulcanoclásticos submarinos: caso de estudo da ilha das Flores, Açores. Provas de Aptidão Científica e Pedagógica. Departamento de Ciências da Terra, Faculdade de Ciências e Tecnologia da Universidade de Coimbra, Coimbra, $198 \mathrm{pp}$.

- $\quad$ Azevedo JM (1999) Geologia e Hidrogeologia da llha das Flores (Açores, Portugal). Tese de doutoramento. Departamento de Ciências da Terra. Faculdade de Ciências e Tecnologia. Universidade de Coimbra, Coimbra, 403 pp.

- Boudouresque C-F, Meinesz A, Verlaque M (1992) Médíterranée. In: Boudouresque CF, et al. (Ed.) Guide des Algues des Mers d'Europe. Delachaux et Niestlé, Paris, 138-231 pp.

- $\quad$ Bridsen D, Forman L (Eds) (1999) The Herbarium Handbook. Third Edition. Kew: The Board of Trustees of the Royal Botanic Gardens, Kew, xii +334 pp.

[ISBN 1-900347-43-1]

- $\quad$ Brodie J, Maggs C, John DM (Eds) (2007) The green seaweeds of Britain and Ireland. British Phycological Society, Dunmurry, Northern Ireland, xii +242 pp.

- $\quad$ Burrows EM (1991) Seaweeds of the British Isles. Vol. 2. Chlorophyta. Natural History Museum, London, xii + 238 pp.

- Cabioc'h J, Floc'h J-Y, Le Toquin A (1992) Manche et Atlantique. In: Boudouresque C-F, et al. (Ed.) Cuide des Algues des Mers d'Europe. Delachaux et Niestlé, Paris, 30-136 pp.

- $\quad$ Cardoso P, Erwin T, Borges PV, New T (2011) The seven impediments in invertebrate conservation and how to overcome them. Biological Conservation 144 (11): 2647-2655. https://doi.org/10.1016/j.biocon.2011.07.024

- Dionísio MA, Micael J, Parente M, Norberto R, Cunha A, Brum J, Cunha L, Lopes C, Monteiro S, Palmero A, Costa AC (2008) Contributo para o conhecimento da biodiversidade marinha da ilha das Flores. XIII Expedição Científica do Departamento de Biologia FLORES E CORVO 2007. Relatórios e Comunicações do Departamento de Biologia, 35: 65-84.

- $\quad$ Dixon SP, Irvine LM (1977) Seaweeds of the British Isles. Vol. I Rhodophyta. Part 1 Introduction, Nemaliales, Gigartinales. British Museum (Natural History), London, $x i+252 \mathrm{pp}$.

- Drouet H (1866) Catalogue de la flore des lles Açores précédé de l'itinéraire d'un voyage dans cet Archipel. Mémoires de la Société Académique de l'Aube 30: 81-233.

- $\quad$ Fletcher RL (1987) Seaweeds of the British Isles. Vol. III. Fucophyceae (Phaeophyceae). Part 1. British Museum (Natural History), London, $x+359$ pp.

- $\quad$ Fralick RA, Hehre EJ (1990) Observations on the marine algal flora of the Azores II. An annotated checklist of the Chlorophyta of the Azores. Arquiplago (Life and Earth Sciences) 8: 11-17.

- $\quad$ Freitas R, Romeiras M, Silva L, Cordeiro R, Madeira P, González JA, Wirtz P, Falcón JM, Brito A, Floeter SR, Afonso P, Porteiro F, Viera-Rodríguez MA, Neto Al, Haroun R, Farminhão JNM, Rebelo AC, Baptista L, Melo CS, Martínez A, Núñez J, Berning B, Johnson ME, Ávila SP (2019) Restructuring of the Macaronesia biogeographic unit: A marine multi-taxon biogeographical approach. Scientific Reports 9 (15792).

https://doi.org/10.1038/s41598-019-51786-6 
- $\quad$ Gain L (1914) Algues provenantdes campagnes de l'Hirondelle II (1911-1912). Bulletin de I'Institut Oceanographique, Monaco 279: 1-23.

- $\quad$ Gayral P, Cosson J (1986) Connaitre et reconnaitre les algues marines. Ouest France, 220 pp.

- Guiry MD, Guiry GM (2020) AlgaeBase. World-wide electronic publication, National University of Ireland, Galway. https://www.algaebase.org. Accessed on: 2020-10-26.

- Hidrogrográfico I (1981) Roteiro do Arquiplago dos Aores. PUB (N) -lli-128-SN, Lisboa.

- Hildenbrand A, Marques FO, Catalão J (2018) Large-scale mass wasting on small volcanic islands revealed by the study of Flores Island (Azores). Scientific Reports 8: 13898. https://doi.org/10.1038/s41598-018-32253-0

- Hortal J, de Bello F, Diniz-Filho JA, Lewinsohn TM, Lobo JM, Ladle RJ (2015) Seven shortfalls that beset large-scale knowledge of biodiversity. Annual Review of Ecology, Evolution, and Systematics 46: 523-549. https://doi.org/10.1146/annurevecolsys-112414-054400

- Irvine LM (1983) Seaweeds of the British Isles. Vol. I. Rhodophyta. Part 2 A. Cryptonemiales (sensu stricto), Palmariales, Rhodymeniales. British Museum (Natural History), London, xii + $115 \mathrm{pp}$.

- Irvine LM, Chamberlain YM (1994) Seaweeds of the British Isles. Vol. 1. Rhodophyta. Part 2B. Corallinales, Hildenbrandiales. Natural History Museum, London, vii +276 pp.

- Lawson GW, John DM (1982) The marine algae and coastal environment of Tropical West Africa. Beihefte zur Nova Hedwigia, J. Cramer, Vaduz, 455 pp.

- Levring T (1974) The marine algae of the archipelago of Madeira. Boletim do Museu Municipal do Funchal 28: 5-111. URL: http://publications.cm-funchal.ptljspui/handle/1 $\underline{00 / 1231}$

- $\quad$ Lloréns JLP, Cabrero IH, Lacida RB, González GP, Murillo FGB, Oñate JJV (2012) Flora marina del litoral gaditano. Biologia, ecologia, usos y guía de identificacíon. $\mathrm{mCN}$ Monografias de Ciencias de la Naturaleza. Servicio de Publicaciones de la Universidad de Cadiz, Cadiz, 368 pp.

- $\quad$ Maggs CA, Hommersand MH (1993) Seaweeds of the British Isles. Vol. 1. Rhodophyta. Part 3A. Ceramiales. Natural History Museum, London, xv +444 pp.

- Morton B, Britton JC, Martins AMF (1998) Coastal Ecology of the Azores. Sociedade Afonso Chaves, Ponta Delgada, 249 pp.

- $\quad$ Neto Al, Azevedo JMM (1990) Contribuição para o estudo dos padrões de zonação litoral da llha das Flores. FLORES/89 - Relatório Preliminar. Relatórios e Comunicações do Departamento de Biologia 18: 89-102. URL: http://hdl.handle.net/ 10400.3/860

- $\quad$ Neto Al, Baldwin HP (1990) Algas marinhas do litoral das ilhas do Corvo e Flores. FLORES/89 - Relatório Preliminar. Relatórios e Comunicações do Departamento de Biologia 18: 103-111. URL: http://hdl.handle.net/10400.3/863

- Neto Al (1996) Flora litoral das ilhas das Flores e Corvo: Inventário, ecologia e afinidades biogeográficas. I. Departamento de Biologia, Universidade dos Açores, 9 pp.

- Neto Al (1997) Flora litoral das ilhas das Flores e Corvo: Inventário, ecologia e afinidades biogeográficas. II. Departamento de Biologia, Universidade dos Açores, $5 \mathrm{pp}$.

- Neto Al (1999) Flora litoral das ilhas das Flores e Corvo: Inventário, ecologia e afinidades biogeográficas. III. Departamento de Biologia, Universidade dos Açores, $23 \mathrm{pp}$. 
- $\quad$ Neto Al, Tittley I, Raposeiro P (2005) Flora Marinha do Litoral dos Açores. [Rocky Shore Marine Flora of the Azores]. Secretaria Regional do Ambiente e do Mar, Açores, 156 pp. URL: http://hdl.handle.net/10400.3/1677 [ISBN 972998840 4]

- $\quad$ Neto Al, Azevedo JMN, Madruga L, Terra MR, Álvaro NV, Azevedo JMM (2008) Candidatura da llha das Flores a Reserva da Biosfera. Gaiaware - Consultoria em Ambiente e Energia, Lda. \& Secretaria Regional do Ambiente e do Mar, Governo dos Açores, vii + 233pp.

- $\quad$ Neto Al, Prestes AC, Álvaro NV, Resendes R, Neto RM, Moreu I (2020a) Marine algal (seaweed) flora of Terceira Island, Azores. Biodiversity Data Journal 8: e57462. https://doi.org/10.3897/BDJ.8.e57462

- $\quad$ Neto Al, Prestes AC, Álvaro NV, Resendes R, Neto RM, Tittley I, Moreu I (2020b) Marine algal flora, of Pico Island, Azores. Biodiversity Data Journal 8: e57461. https://doi.org/10.3897/BDJ.8.e57461

- $\quad$ Neto AI, Parente MI, Botelho AZ, Prestes AC, Resendes R, Afonso P, Álvaro NV, MillaFigueras D, Neto RM, Tittley I, Moreu I (2020c) Marine algal flora of Graciosa Island, Azores. Biodiversity Data Journal 8: e57201. https://doi.org/10.3897/BDJ.8.e57201

- $\quad$ Neto Al, Parente MI, Tittley I, Fletcher RL, Farnham WF, Costa AC, Botelho AZ, Monteiro S, Resendes R, Afonso P, Prestes ACL, Álvaro NV, Milla-Figueras D, Neto RMA, Azevedo JMN, Moreu I (2020d) Marine algal flora of Flores and Corvo Islands, Azores. 1.4. Universidade dos Açores. Dataset/Samplingevent. Release date:

2020-11-15. URL: http://ipt.gbif.pt/ipt/resource?r=flores-corvo seaweed flora\&v=1.4

- Rodríguez-Prieto C, Ballesteros E, Boisset F, Afonso-Carrillo J (2013) Guía de las macroalgas y fanerógamas marinas del Mediterráneo Occidental. Ed. Omega, S.A., Barcelona, $656 \mathrm{pp}$.

- Schmidt OC (1929) Beitrage zur Kenntnis der Meeresalgen der Azoren. I. Hedwigia 69: 95-11.

- Schmidt OC (1931) Die marine vegetation der Azoren in ihren Grundzügen dargestellt. Bibliotheca Botanica 24 (102): 1-116, 10 Tafl.

- Taylor WR (1967) Marine algae of the northeastern coasts of North America. The University of Michigan Press, viii +509 pp.

- Taylor WR (1978) Marine algae of the eastern tropical and subtropical coasts of the Americas. The University of Michigan Press, xxi +870 pp.

- Tittley I, Neto Al (1996) Marine algae of the Island of Flores, Azores: Floristics and ecology. II Simpósio Fauna e Flora das Ilhas Atlânticas, Abstract Book, Las Palmas, 12-16/02. Gran Canaria URL: http://hdl.handle.net/10400.3/1768

- Tittley I, Neto Al, Farnham WF (1998) Marine algae of the Island of Flores, Azores: Ecology and floristics. Boletim do Museu Municipal do Funchal, Sup 5: 463-479. URL: http://hdl.handle.net/10400.3/1688

- Tittley I, Neto Al (2000) A provisional classification of algal characterized rocky shore biotopes in the Azores. Hydrobiologia 440: 19-25. https://doi.org/10.1023/A: 1004172321900

- Tittley I (2003) Seaweed diversity in the North Atlantic Ocean. Arquiplago Life and Marine Sciences 19A: 13-25.

- Tittley I, Neto Al (2005) The marine algal (Seaweed) flora of the Azores: additions and amendments. Botanica Marina 48: 248-255. https://doi.org/10.1515/BOT.2005.030

- Tittley I, Neto Al (2006) The marine algal flora of the Azores: Island isolation or Atlantic stepping stones? Occasional papers of the Irish Biogeographical Society 9: 40-55. 
- Trelease W (1897) Botanical observations on the Azores. Eigth Annual Report of the Missouri Botanical Garden: 76-213. https://doi.org/10.2307/2992160

- Wallenstein FM, Neto Al, Álvaro NV, Tittley I, Azevedo JMN (2009) Guia para Definição de Biótopos Costeiros em Ilhas Oceânicas. [Coastal Biotope Definition Manual for Oceanic Islands]. Secretaria Regional do Ambiente e do Mar URL: http://hdl.handle.net/ $\underline{10400.3 / 1687}$ [ISBN 978-972-99884-9-3]

\section{Supplementary material}

\section{Suppl. material 1: DP-FLOR+COR-id_15074_normalized.csv doi}

Authors: Ana I Neto

Data type: Macroalgae taxonomic mismatching

Brief description: GBIF does not have the more actualised nomenclature for some of the macroalgae species names. Therefore, the matching tools of its platform were applied to the species list, as required by Pensoft's data auditor, to identify the problematic taxonomic situations. The resulting file (DP-FLOR+COR-id_15074_normalized.csv) is included here, since the names will not be immediately updated in the GBIF Taxonomic Backbone. A request was already sent to GBIF helpdesk to solve this situation.

Download file $(35.03 \mathrm{~kb})$ 